\title{
Prematürede anemi ve transfüzyon politikaları
}

\author{
Anemia and transfusion policies in premature infants
}

\author{
Özmert M.A. Özdemir
}

\section{Öz}

Yenidoğan döneminde anemi, fizyolojik olabildiği gibi prenatal, perinatal ve postnatal pek çok neden sonucu gelişebilmekte, ancak özellikle aşırı prematüre bebeklerde en önemli anemi nedenlerinden birisini iyatrojenik kan kayıpları oluşturmaktadır. Anemi saptanan bir yenidoğanda eritrosit transfüzyon kararı doku oksijenizasyonunu optimize edecek kan hemoglobin veya hematokrit düzeylerinin devamlılığının sağlanması amacıyla verilmektedir. Bunun için ise pratikte bebeğin kan hemoglobin ve/veya hematokrit düzeyi ve klinik durumu önem kazanmaktadır. Eritrosit transfüzyonunun pek çok potansiyel kompliksayonu da düşünüldüğünde prematüre bebeklere eritrosit transfüzyonu kararı verilirken kar-zarar oranı gözetilerek, güncel uygulamalar ışığında klinik bulguları eşliğinde bireyselleştirilmiş transfüzyon kararı verilmesi uygun gözükmektedir, ancak asıl amaç prematüre bebeklerde anemi gelişiminin önlenmesi olmalıdır.

Bu derlemede prematüre anemisi, tanısı, transfüzyon tedavisi, komplikasyon ve korunma stratejileri son güncel uygulamalar ışığında verilmeye çalışıımıştır.

Anahtar kelimeler: Prematüre bebek, anemi, transfüzyon.

Özmert MAÖ. Prematürede anemi ve transfüzyon politikaları. Pam Tıp Derg 2022;15:407-424.

\begin{abstract}
In the neonatal period, anemia may be physiological as well as many prenatal, perinatal and postnatal causes; however, especially in some extremely premature infants, one of the most important causes of anemia is iatrogenic blood losses. The decision of red blood cells transfusion in a newborn with anemia is made in order to maintain blood hemoglobin or hematocrit levels which will optimize tissue oxygenation. For that, the baby's blood hemoglobin and/or hematocrit level and clinical status are important practically. Considering the many potential complications of red blood cells transfusion, it seems appropriate to make an individualized transfusion decision in the light of current practices and clinical findings while deciding on transfuison of red blood cells for premature infants, however the main goal should be to prevent the development of anemia in premature infants. In this review, anemia of prematurity, diagnosis, transfusion therapy, complications and prevention strategies have been tried to be given in the light of recent current practices.
\end{abstract}

Key words: Preterm infant, anemia, transfusion.

Ozmert MAO. Anemia of prematurity and transfusion. Pam Med J 2022;15:407-424.

\section{Giriş}

Anemi hemoglobin $(\mathrm{Hb})$ veya hematokrit (Htc) değerinin yaş için ortalamanın 2 standard deviasyon altında olması olarak tanımlanır [1]. Anemi yenidoğan döneminde fizyolojik olabileceği gibi prenatal, perinatal veya postnatal bazı komplikasyonlar (feto-maternal kanama, umblikal kord/plasenta anomalileri, travmatik doğum, izoimmün hemolitik hastalıklar, trombositopeni, enfeksiyonlar, vb) sonucu gelişebilir, ancak özellikle aşırı prematüre bebeklerde en önemli anemi nedenlerinden birisi laboratuvar testleri için sıklıkla alınan iyatrojenik kan kaybıdır [1-4]. Bu kan kaybının yenidoğan yoğun bakım ünitelerinde izlenen prematüre bebeklerin postnatal ilk ayında total vücut kanının 1/3'ünü bulabileceği belirtilmektedir [4]. Kapiller ölçülen $\mathrm{Hb}$ değerlerinin venöz $\mathrm{Hb}$ değerinden daha yüksek olduğu, en düşük $\mathrm{Hb}$ değerlerinin umblikal kordondan alınan venöz kanda saptandığı bildirilmektedir [1]. Gebelik yaşı >34 hafta bebeklerde; venöz $\mathrm{Hb}<13 \mathrm{gr} / \mathrm{dl}$ veya kapiller $\mathrm{Hb}<14,5 \mathrm{~g} / \mathrm{dl}$ olması anemi olarak değerlendirilir ve yenidoğanın en sık hematolojik sorunu olarak görülmektedir [2]. Geç preterm ve term bebeklerde ortalama venöz $\mathrm{Hb}$ değerleri 14-20 g/dl arasında iken retikülosit sayısı \%3-7 arasındadır. Daha prematüre bebeklerde $\mathrm{Hb}$ değeri daha düşük ve retikülosit sayısı biraz daha yüksektir. Hemoglobin değeri term sağlıklı bebeklerde postnatal üçüncü haftaya kadar değişmezken, daha sonrasında (8-12 
haftalarda) ortalama $11 \mathrm{~g} / \mathrm{dl}$ 'e kadar (en düşük 9 $\mathrm{g} / \mathrm{dl}$ ) düşer, buna fizyolojik anemi denilmektedir. $\mathrm{Bu}$ durum prematüre bebeklerde 4-8 haftalar arasında gerçekleşir ve $\mathrm{Hb}$ değeri 7-9 g/dl'e kadar düşebilir [1, 2]. Prematüre bebekler prematüre anemisi olarak adlandırlan çok daha düşük $\mathrm{Hb}$ değelerine sahiptir. Prematüre anemisinin doğumda gestasyonel yaşa göre düşük $\mathrm{Hb}$ değeri, kısa eritrosit ömrü, endojen eritropoetin (EPO) üretim azlığı, hiporejeneratif kemik iliği, medikal komplikasyonlar, iyatrojenik kan kaybı ve hızlı vücut büyümesi ile ilişkili olduğu belirtilmektedir [1, 2, 5, 6].

Bu yazıda prematüre anemisi nedenleri, tanı ve tedavisi son literatürler eşliğinde tartışılmış ve güncel uygulamalar verilmeye çalışılmıştır.

\section{Etiyopatogenez}

Eritrositleroksijenin dokulara ulaştırılmasında rol alan hücreler olup, bunu da $\mathrm{Hb}$ aracılığıyla yapmaktadır. Hemoglobinin oksijene affinitesi sıcaklık, pH, karbondioksit basıncı $\left(\mathrm{PCO}_{2}\right)$ ve eritrosit içindeki 2,3 difosfogliserat 2,3-DPG düzeyi ile yakından ilişkilidir. Örneğin yetişkin $\mathrm{Hb}\left(\begin{array}{ll}\mathrm{Hb} & \mathrm{A}\end{array}\right)$ oksijen affinitesi $\mathrm{pH}$ ile doğru, ancak sıcaklık ve 2,3-DPG ile ters ilişkilidir [1]. Ortamda $\mathrm{pH}$ arttıkça veya 2,3-DPG, $\mathrm{PCO}_{2}$ ve sıcaklık azaldıkça Hb'nin oksijene affinitesi artmakta, tersi durumda ise $\mathrm{Hb}$ oksijen affinitesi azalmaktadır [1, 7]. Eritrosit yapımı konsepsiyondan 2-3 hafta sonra embriyonel dönemde yolk sac kesesinde başlar, ilk trimestir sonuna doğru fetal karaciğere geçen eritrosit üretimi, doğuma kadar burada devam ederken, ikinci trimestir sonunda kemik iliği primer eritropoezis görevini üstlenir [7]. Fetal dönem ve yenidoğanda baskın $\mathrm{Hb}$ ise $\mathrm{Hb}$ F'dir. Fetal $\mathrm{Hb}$ $(\mathrm{Hb} F)$ oksijen affinitesi yüksektir. Doğumdan sonra postnatal ilk 6 ayda $\mathrm{Hb} F$ azalırken $\mathrm{Hb} \mathrm{A}$ artmaya başlar, 6 aydan sonra $\mathrm{Hb} F$ \%1'in altına düşerken, dominant $\mathrm{Hb}$ yetişkin tipi $\mathrm{Hb}$ yani $\mathrm{Hb}$ A olur, bu arada $\mathrm{Hb} \mathrm{A}_{2}$ (minör yetişkin $\mathrm{Hb}$ grubu) de postnatal birkaç ay içerisinde tedrici olarak $\operatorname{artar}[1,7]$.

Eritropoetin eritropoezisden sorumlu bir glikoprotein olup, öncü eritroid progenitör hücrelerin üzerinde bulunan eritropoetin reseptörlerine bağlanır ve JAK2 sinyal yolağı üzerinden eritrosit üretimini (apopitozisi önleyerek) düzenler. Eritropoetin primer olarak fetal karaciğerde, sonrasında ise böbreğin kortikal peritübüler hücrelerinden üretilir.
Yetişkinde EPO'nun en önemli üretim yeri böbreklerdir. Eritropoezis kandaki oksijen konsantrasyonuna oldukça hassastır ve hipoksik durumda EPO üretimi artmaktadır [1]. Yaklaşık $\% 50$ olan fetal $\mathrm{Hb}$ oksijen konsantrasyonu doğumdan hemen sonra dakikalar içinde \%95 ve üstüne çıkar [8]. İntrauterin dönemde yüksek olan EPO doğum sonrası intrauterin döneme göre doku oksijen konsantrasyonunun yüksekliği sebebiyle hızla azalır. Sağlıklı term bebeklerde en düşük düzeylerine 1 ay civarında ulaşırken, 2. ayda artarak maksimum düzeylere gelir ve sonrasında yetişkin düzeylerine doğru yavaş bir geçiş olur. Postnatal doku oksijen konsantrasyonu ve EPO üretim değişikliği yenidoğanlardaki fizyolojik anemi gelişiminden sorumlu tutulmaktadır. Prematüre bebeklerde daha kısa eritrosit ömrü (30-50 gün) ve düşük EPO düzeyleri nedeniyle en düşük $\mathrm{Hb}$ düzeyleri 6. haftada 7-10 g/dl'e kadar düşebilir. Çok düşük doğum ağırlıklı (ÇDDA, <1500 gr) ve aşırı düşük doğum ağırlıklı (ADDA, <1000 gr) bebeklerde $\mathrm{Hb}$ değeri doğumdaki değerinin \%20'sinden daha fazla düşebilir. Ayrıca bu bebeklerde kan kaybına neden olabilecek başka nedenler ve EPO üretiminin baskılanması gibi nedenler daha ciddi ve erken dönemde anemi gelişmesine sebep olur [1]. Prematüre bebeklerde hipoksiye EPO cevabı (EPO klerensinin yüksek olması, hızlı dağılımı ve hızlı eliminasyonu nedeniyle) term bebeklere kıyasla daha yetersizdir [1, 8]. Şekil 1, Şekil 2'de doğumda gestasyonel haftaya göre referans $\mathrm{Hb}$ ve Htc değerleri, Şekil 3-6'da ise 29-42. gebelik haftaları arasında doğan bebeklerin postnatal ilk 28 gündeki $\mathrm{Hb}$ ve Htc referans değerleri gösterilmiştir [9].

Prematüre bebeklerde, özellikle ADDA bebeklerin yenidoğan ünitelerinde izlemi sırasında, yaşamın ilk haftalarında flebotomi ile iyatrojenik kan kaybının (yaklaşık 11-22 ml/ $\mathrm{kg} /$ hafta) prematüre anemisi gelişiminde önemli etkileri vardır. Yine prematüre bebeklerde daha düşük eritrosit ömrü, EPO yetersizliği, eritropoezis için gerekli mikro nutrientlerin (demir, folat, protein, $E$ vitamini ve B12 vitamininin doğumda depolarının düşüklüğü, enteral beslenme yetersizliği veya gastrointestinal sistem immatüritesine bağlı emilim yetersiziliği gibi nedenlerden dolayı) rölatif eksikliği ve prematürenin ko-morbid durumları (kronik akciğer hastalığı, sepsis gibi) prematüre anemisi gelişiminde oldukça önemli etkilere sahiptir. Genel olarak, prematüre anemisi şiddeti düşük 


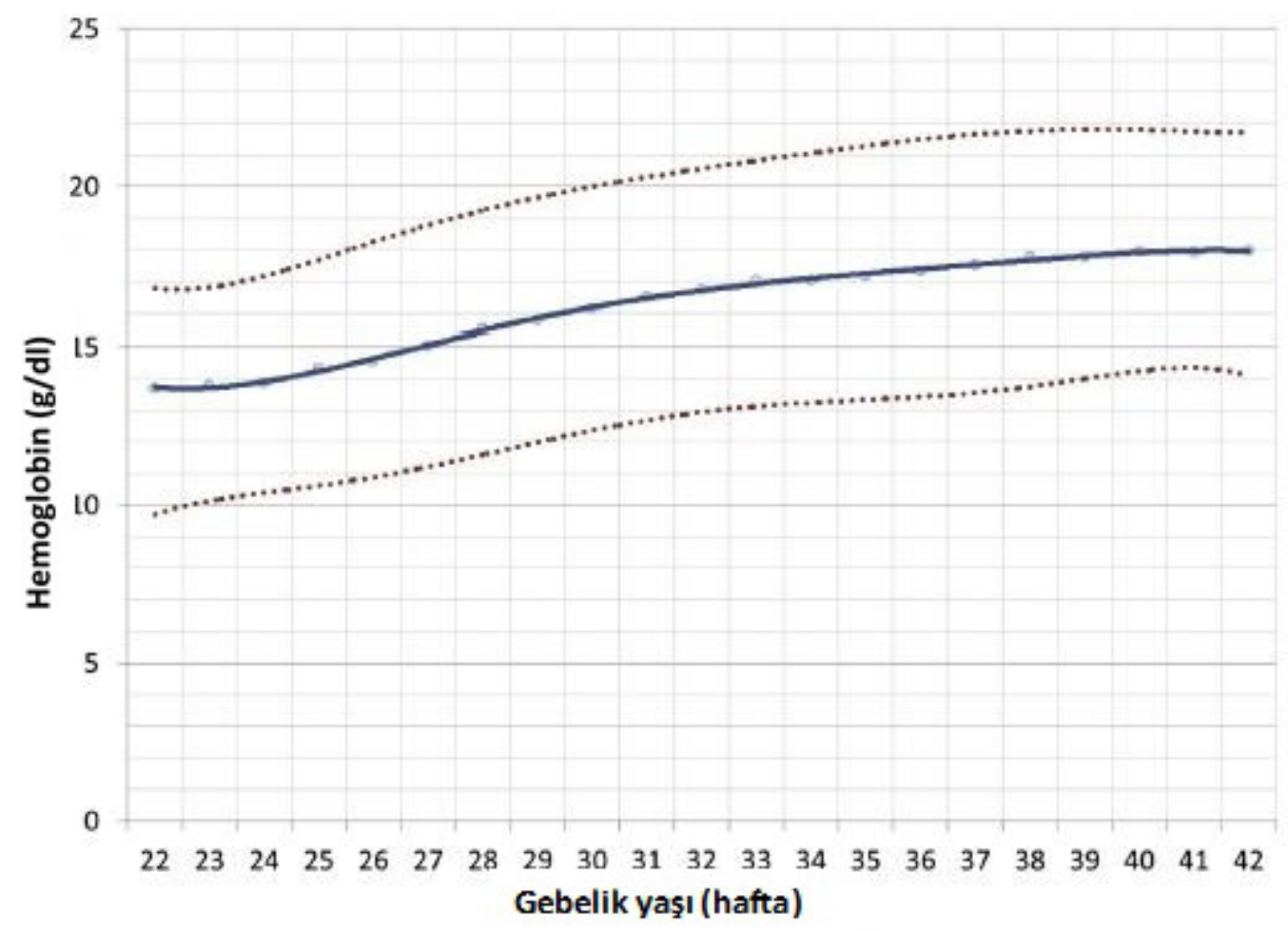

Şekil 1. Gestasyonel yaşa göre Hb eğrisi [9]

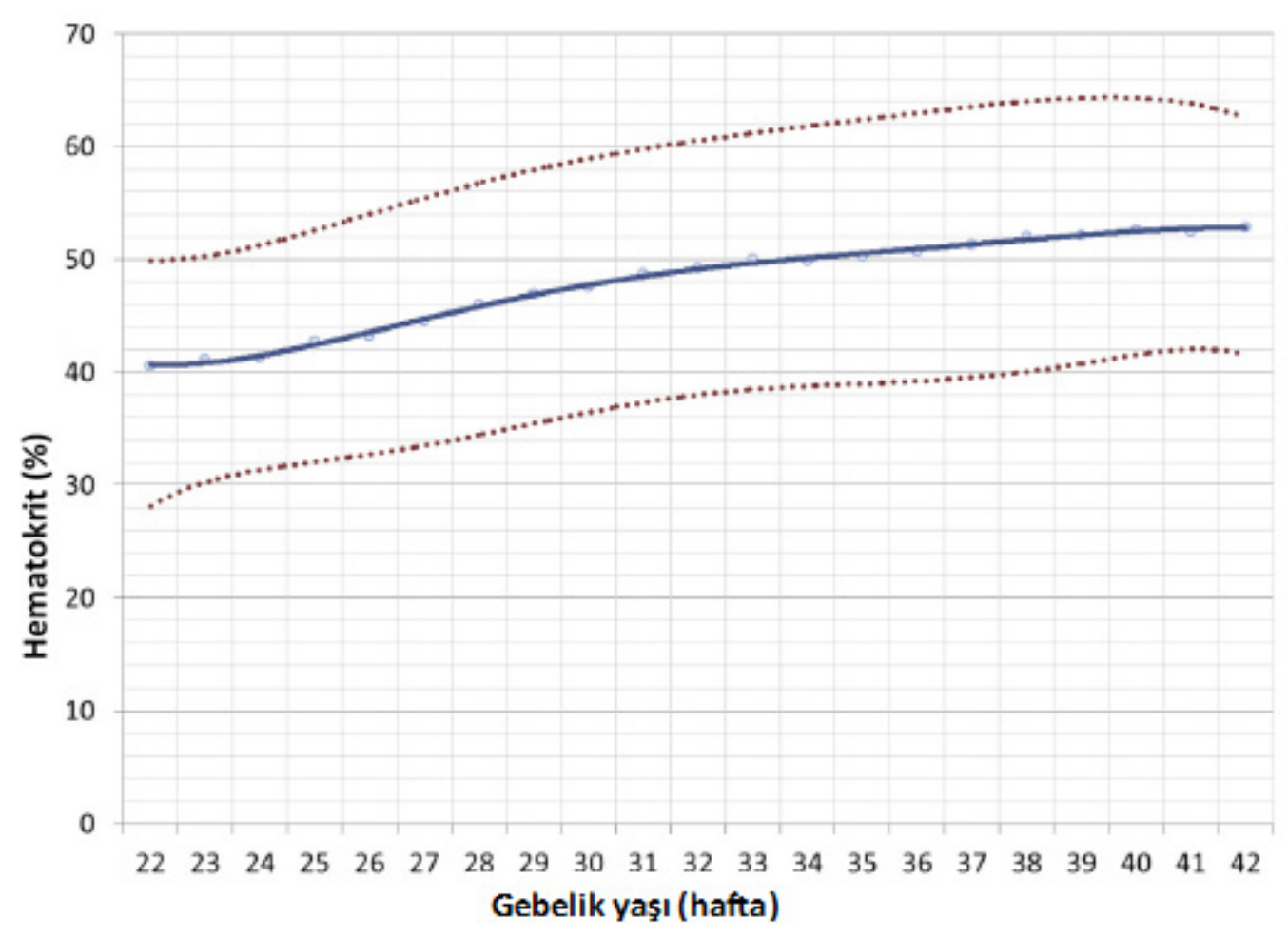

Şekil 2. Gestasyonel yaşa göre Htc eğrisi [9] 


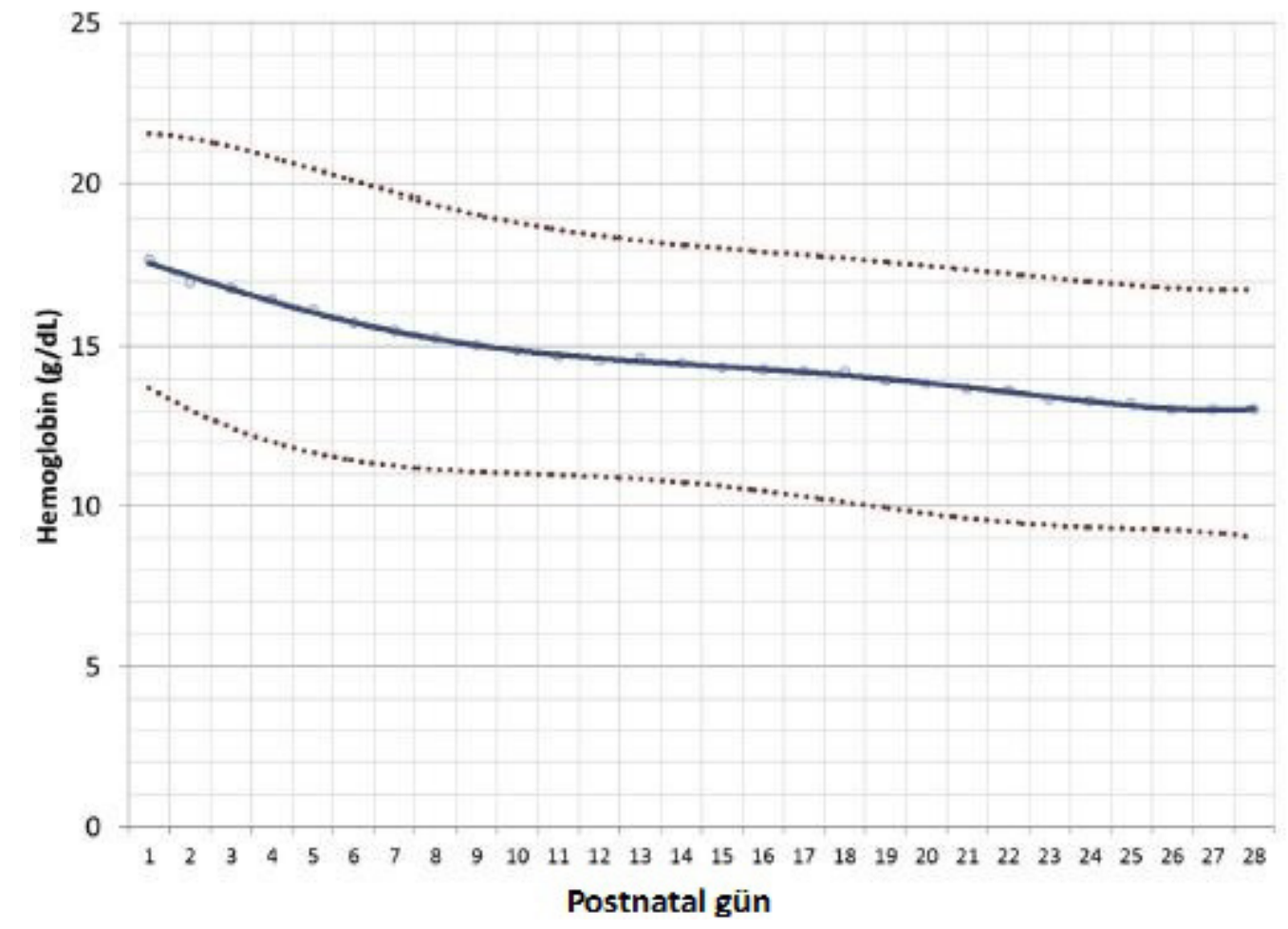

Şekil 3. 35-42 haftalık doğan bebeklerin postnatal 28 günlük Hb değerleri [9]

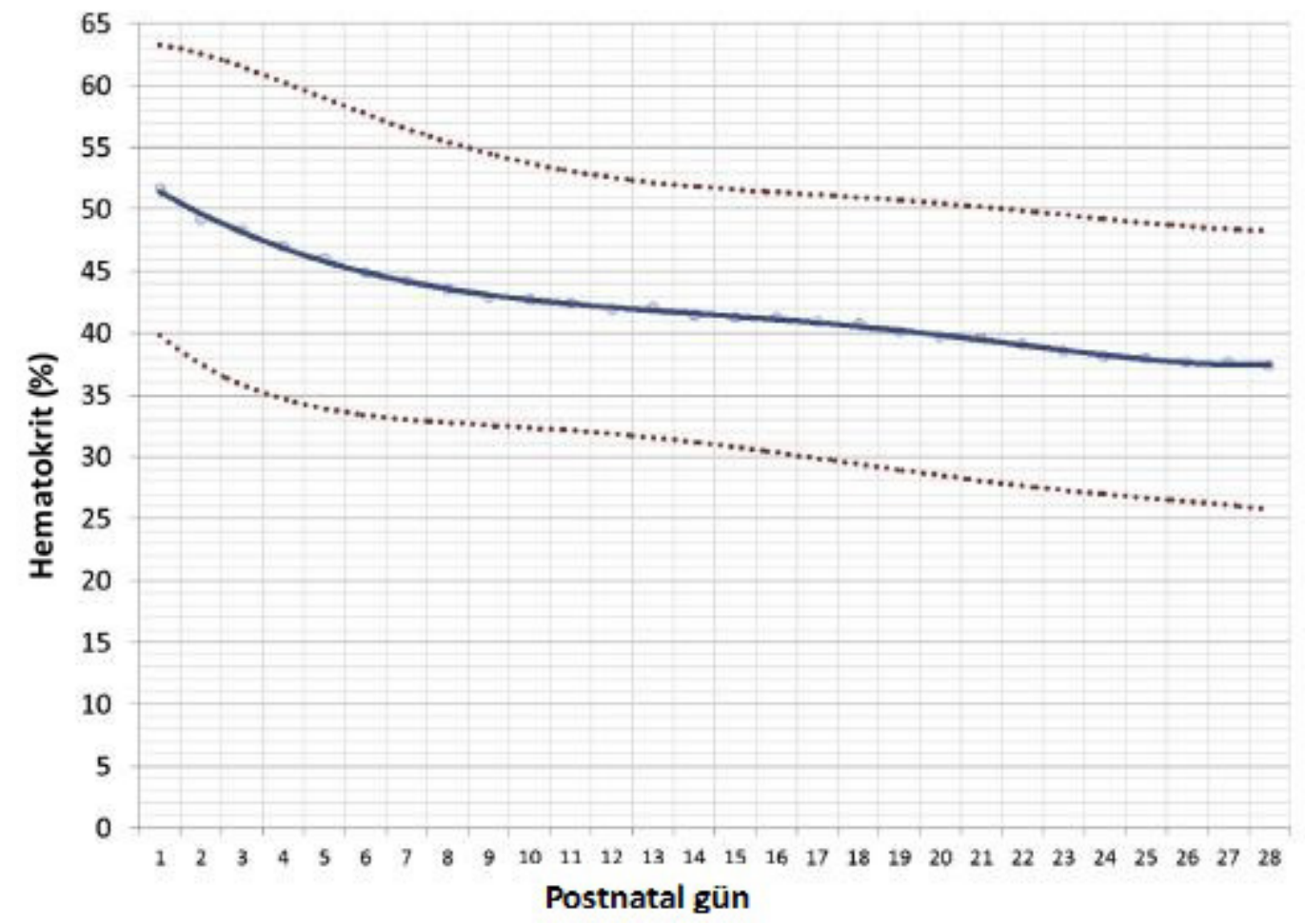

Şekil 4. 35-42 haftalık doğan bebeklerin postnatal 28 günlük Htc değerleri [9] 


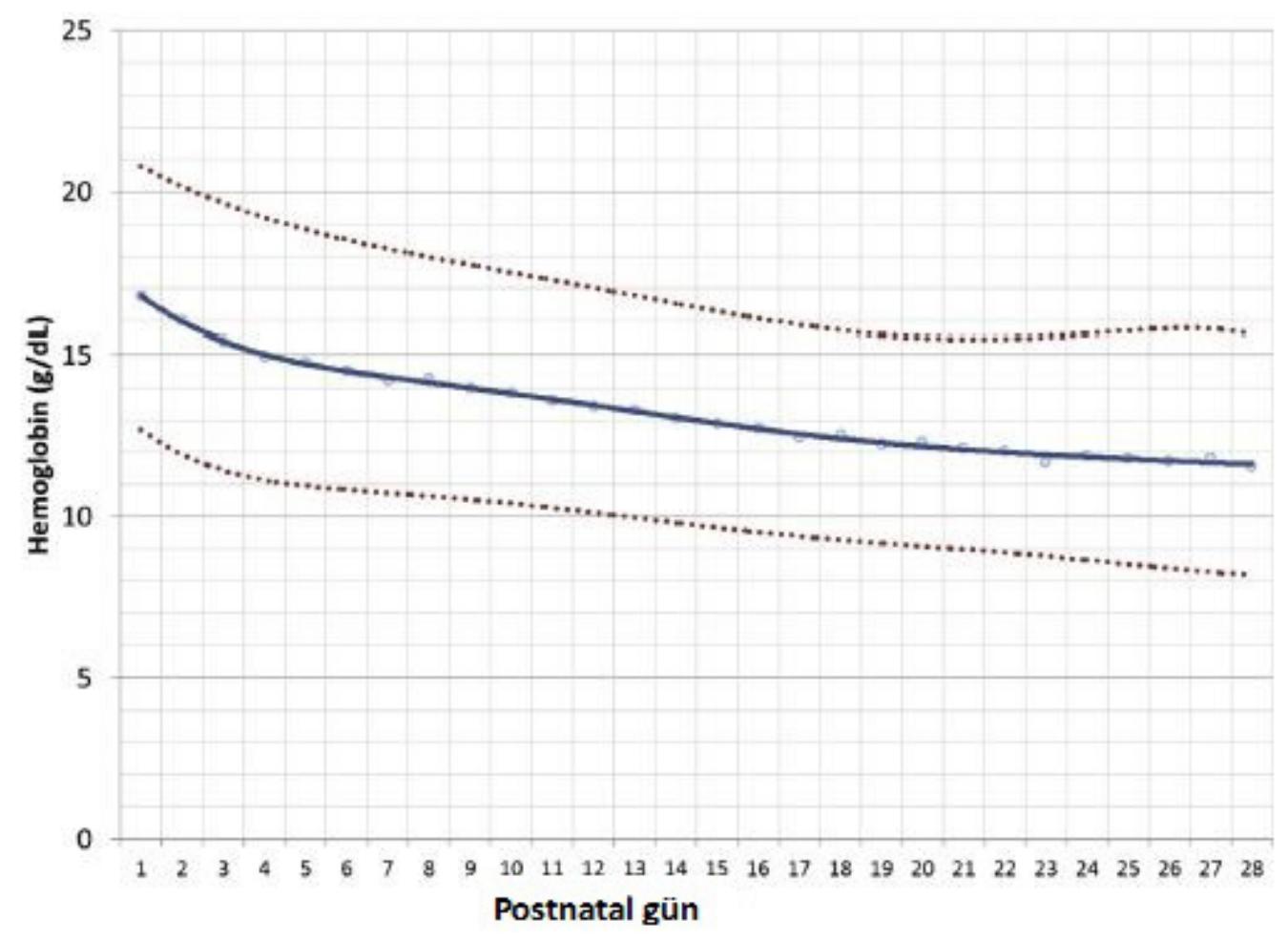

Şekil 5. 29-34 haftalık doğan bebeklerin postnatal 28 günlük Hb değerleri [9]

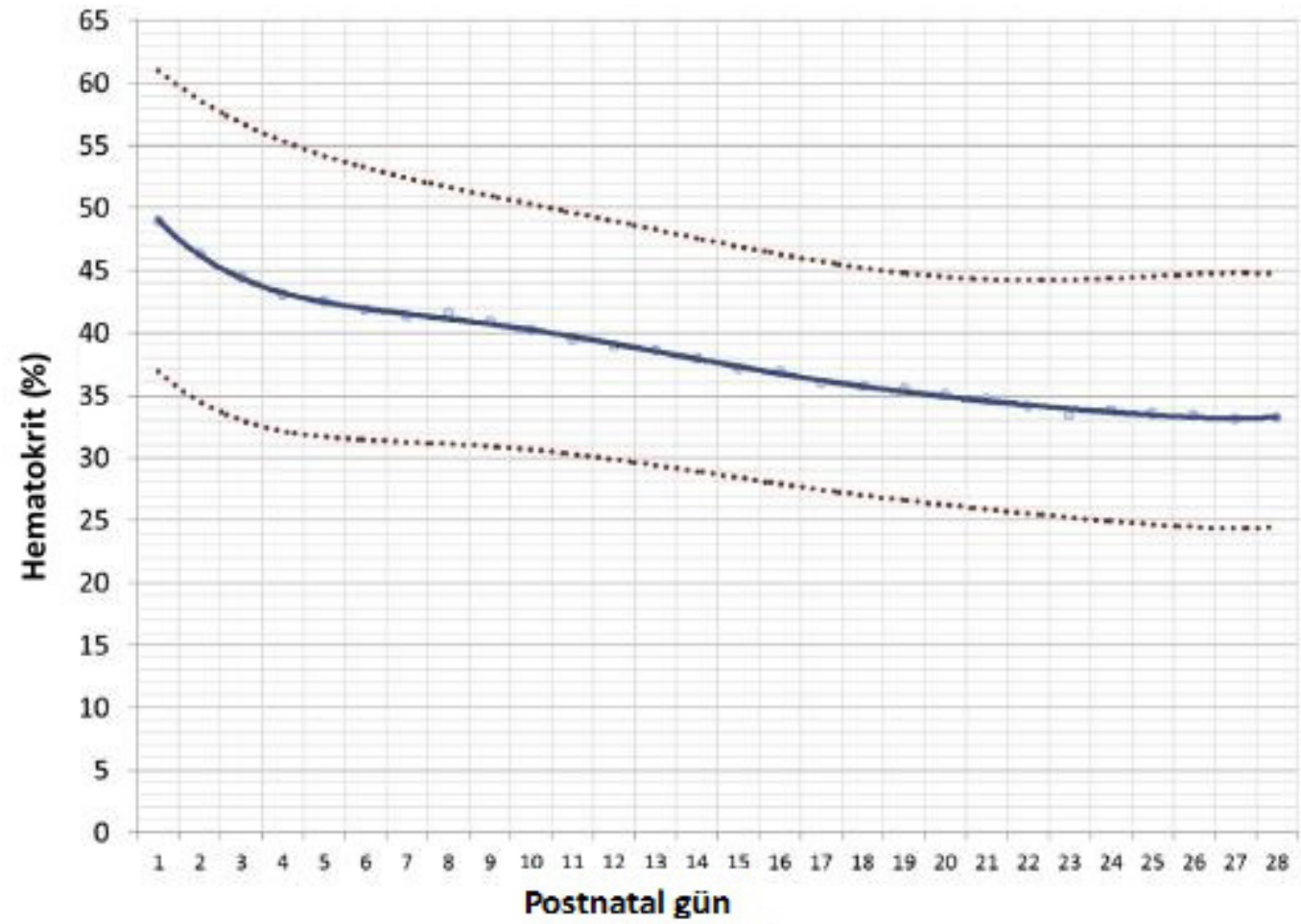

Şekil 6. 29-34 haftalık doğan bebeklerin postnatal 28 günlük Htc değerleri [9] 
gestasyonel yaş ve doğum ağırlığı ile doğru orantılıdır [10].
Yenidoğan döneminde anemi sıklıkla kan kaybına bağlı gelişmekle birlikte eritrosit üretim

Tablo 1. Yenidoğanda anemi nedenleri [1-3]

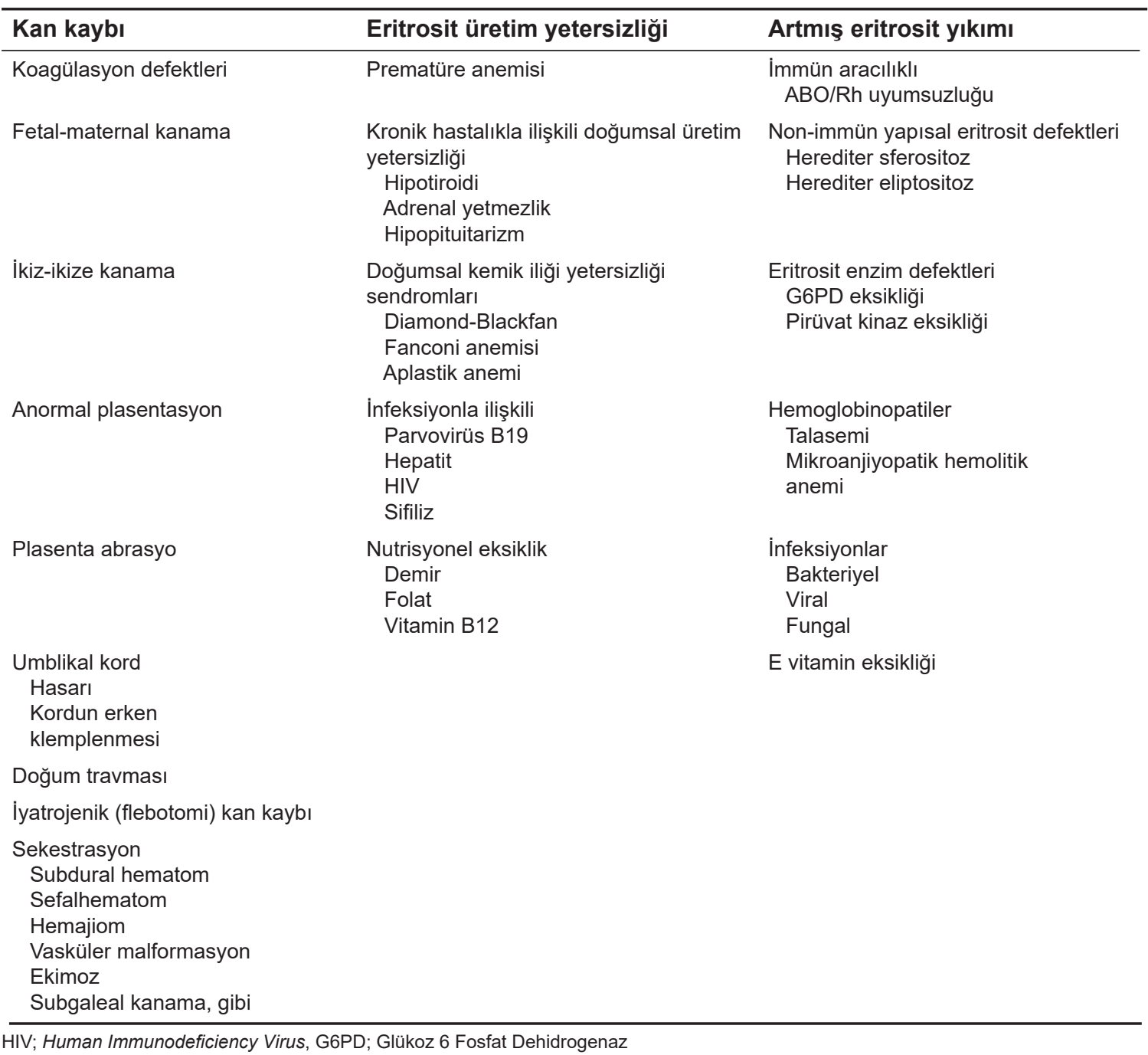

yetersizliği ve artmış eritrosit yıkımı diğer etiyolojik nedenleri oluşturmaktadır (Tablo 1) [13].

\section{Klinik bulgular}

Anemi ile ilişkili klinik bulgular; apne, gelişme geriliği, letarji, desatürasyon, bradikardi, taşikardi ve oksijen intiyacında artma olarak sayılabilir. Bu bulgular non-spesifik olup anemi dışı başka hastalıkların (sepsis, respiratuvar distres veya gastro-özefageal reflü gibi) klinik belirtileriyle karışabilmekte, ayrıca bazı klinik girişimler (antibiyoterapi, mekanik ventilasyon, beslenme gibi) de klinik tablonun karışmasına neden olabilmektedir [11, 12]. Genel olarak; anemi taşikardi, hipotansiyon, perfüzyonda ve doku oksijenizasyonunda azalmaya neden olmaktadır. Bu bulgulardan taşikardinin daha değerli bir bulgu olduğu belirtilmektedir. Yapılan çalışmalarda eritrosit transfüzyonuyla apne, bradikardi, desatürasyon, taşikardi ve oksijen intiyacının anlamlı şekilde transfüzyon sonrası düzeldiği belirtilmekle birlikte bazı çalışmalarda kalp hızı üzerine anlamlı etkilerinin olmadığı da bildirilmektedir [12].

Son zamanlarda eritrosit transfüzyon kararı vermede klinik olarak near-infrared spectroscopy (NIRS) kullanımı gündeme gelmiştir. Noninvazif ve hasta başı kolay uygulanabilen bu yöntemle bölgesel perfüzyon ve metabolizmayı yansıtan doku oksijen satürasyonu $\left(\mathrm{rSO}_{2}\right)$ veya doku oksijen indeksi ölçülmektedir. Fraksiyonel doku oksijen ekstraksiyonu (FTOE; doku oksijenizasyonu ile tüketimi 
arasındaki dengeyi yansıtmaktadır) diğer bir değerlendirme yöntemidir. Eritrosit transfüzyon öncesi ve sonrası anemik prematürelerde yapılan çalışmalarda: transfüzyonun serebral, renal ve splanik doku oksijenizasyonunu düzelttiği ve FTOE'yi azalttığı belirtilmektedir. Anemi saptanan semptomatik prematürelerde asemptomatik bebeklere kıyasla periferal FTOE'nin anlamlı yüksek olduğu ve bunun eritrosit transfüzyon intiyacını belirlemede bir markır olabileceği belirtilmektedir [12].

$\mathrm{Bu}$ konuda en son 2021 yılında prematüre bebeklerde 38 çalışmanın dahil edildiği derlemede; aneminin ve eritrosit transfüzyonunun, transfüzyon öncesi ve sonrası serebral oksijen satürasyonu, FTOE ve nörogelişimsel sonuç üzerine etkileri değerlendirilmiştir. Düşük $\mathrm{Hb}$ düzeylerinde azalmış serebral $\mathrm{rSO}_{2}$ veya artmış serebral FTOE arasında güçlü bir ilişki olduğu ve eritrosit transfüzyonuyla serebral $\mathrm{rSO}_{2}$ 'nin arttığı görülmüştür. En iyi nörogelişimsel sonuçların serebral $\mathrm{rSO}_{2}$ \%72-83 arasında olabileceği (normal serebral rSO2 aralığı \%65-75) belirtilmekte, ayrıca artmış serebral FTOE'nin anemiye erken bir fiyolojik yanıt olarak bu bebeklerde değerli bir bulgu olabileceği ve mevcut bilgilerle kıstlı eritrosit transfüzyon stratejisinin daha iyi nörogelişimsel sonuçları destekler gözüktüğü rapor edilmiştir [13].
Sonuç olarak, eritrosit transfüzyonu doku oksijenizasyonunu düzeltmekte ve dolayısıyla doku oksijenizasyon düzeylerinin eritrosit transfüzyonu gereksiniminin belirlenmesinde önemli bir role sahip olabileceği bildirilmekte ve bununla ilgili olarak "The Transfusion of Prematures" TOP çalışması sonuçlarının önemli bilgiler verebileceği bildirilmiştir [12].

\section{Tanı}

Doğumsal geçişli herediter sferositoz, enzim defektleri ya da koagülasyon bozukluğu gibi bazı hastalıklar açısından uyarıcı olması nedeniyle iyi bir aile öyküsü (ailenin diğer üyelerinde anemi, kanama, sarılık, kolelithiazis ve splenektomi sorgulanmalı) ile birlikte doğum travması, vajinal kanama (plasental anormallik), kord rüptürü ve çoğul gebelik açısından ayrıntılı doğum öyküsü alınmalıdır [14, 15]. Aneminin saptandığı yaş da önemlidir. Postnatal ilk günlerde ciddi anemi (<48 saat) saptanması sıklıkla hemorajik ya da ciddi alloimmünizasyon sonucu görülürken, daha sonrasında anemi saptanması sıklıkla hemolitik bir durumla ilişkili ve sıklıkla sarılıkla birliktelik gösterir [14]. Anemi düşünülen olgularda mutlaka hemogram $(\mathrm{Hb}$, $\mathrm{Htc}$, eritrosit indeksleri; "mean corpuscular volume" MCV, gibi), retikülosit sayısı, periferik yayma, direkt Coombs testi değerlendirilmelidir $[2,14]$. Yenidoğanda anemiye tanısal yaklaşım

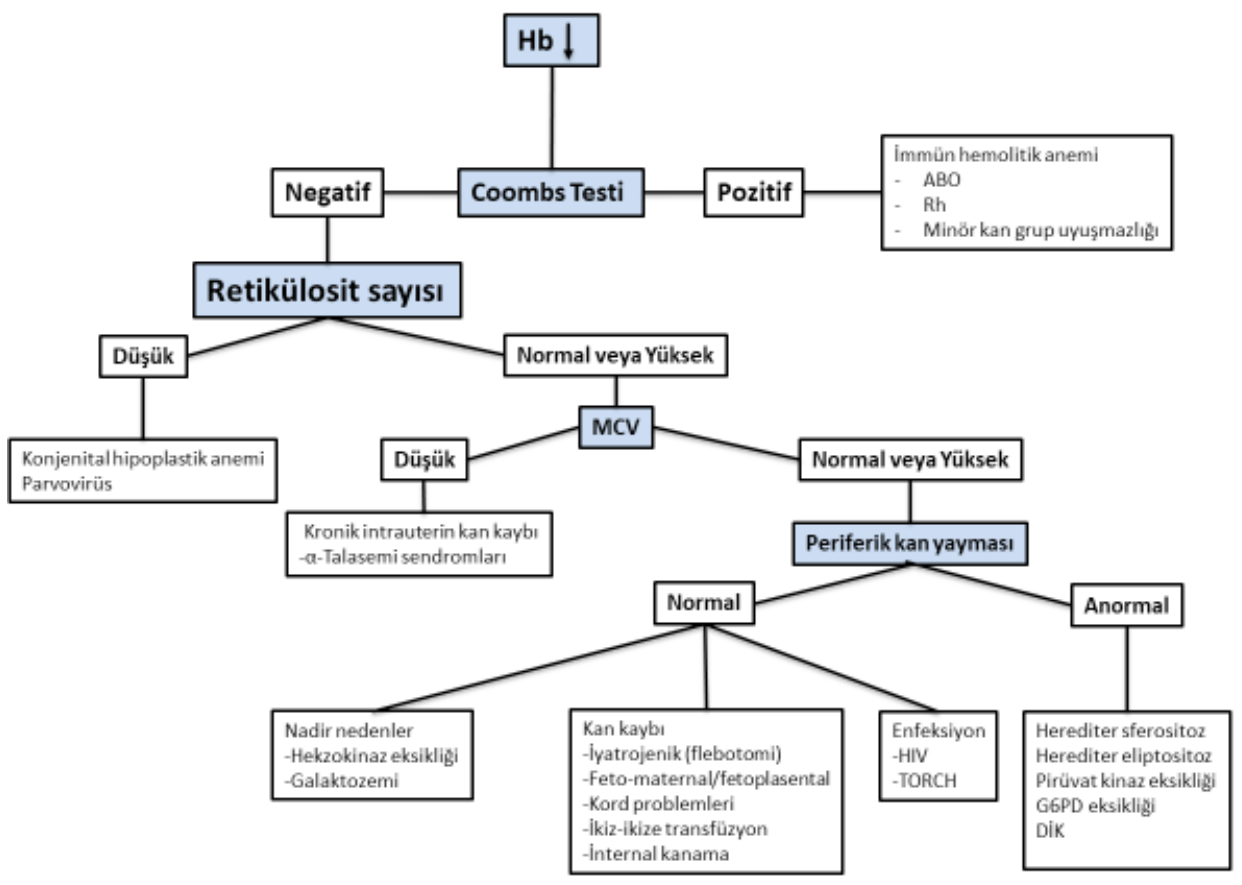

Şekil 7. Yenidoğan anemisine tanısal yaklaşım $[7,14,15]$ 
Şekil 7'de ayrıntılı olarak verilmiştir [7, 14, 15]. Gerekli durumlarda; anne ve bebek kan grubu tayini, feto-maternal kanama için KleihauerBetke testi, yenidoğan enfeksiyonu ile ilgili testler ("toksoplazma, rubella, sitomegalovirüs, herpes simpleks" TORCH grubu veya diğer enfeksiyonlarla ilişkili serolojik testler), koagülasyonla ilgili tetkikler, gizli kanama şüphesinde ultrasonografik inceleme (kraniyal ve batın), eritrosit enzim ya da membran defekti incelemeleri, hemoglobin elektroforezi veya doğumsal hipoplastik ya da aplastik anemi tanısı için kemik iliği incelemesi ve nutrisyonel değerlendirme gibi daha ileri tetkikler hastanın klinik ve laboratuvar bulgularına göre planlanabilir [2, 14, 15].

Yenidoğanlarda normal $\mathrm{Hb}$ değerleri için Türk Neonatoloji Derneği (TND) 2021 Kan Ürünleri Transfüzyon Rehberi önerisi Tablo 2'de gösterilmektedir. Bu tabloda prematür bebekler $<37$ gestasyonel hafta altı doğum olarak tanımlanıp, bu bebeklerde gestasyonel haftaya ve çalışılan laboratuvara göre değişiklikler olabileceği belirtilmektedir [16].

\section{Transfüzyon endikasyonu}

Yenidoğan bebekte eritrosit trasfüzyon kararı esas olarak doku oksijenizasyonunu optimize edecek kan $\mathrm{Hb}$ veya Htc düzeylerinin devamının sağlanabilmesi amacıyla verilmektedir. Ancak, gerçekte Htc düzeyleri ve diğer biyokimyasal markırlar doku oksijen düzeylerini belirlemede iyi birer gösterge değillerdir. Pratik olarak bir yenidoğana transfüzyon kararı Htc düzeyi ve klinik duruma göre verilmelidir [11]. Eritrosit transfüzyonu için üniversal bir uzlaşı bulunmamakta, ülkeler arası hatta aynı ülkede klinikler arası bile farklı uygulamalar ve rehberler bulunmaktadır [4, 11, 12, 16]. Ayrıca belirtilen bu $\mathrm{Hb}$ eşik değerleri de her prematüre bebek için uygun olmayabilir. Dolayısıyla hekimin transfüzyon kararı bebeğin klinik bulguları temelinde ulusal veya bölgesel rehberlere göre yapılması en uygunu olanıdır [12]. Üstelik transfüzyonla ilişkili bazı yan etkilerin (infeksiyon, allo-immünizasyon, febrilallerjik ve hemolitik reaksiyonlar, "nekrotizan enterokolit" NEK ve "intraventriküler kanama" IVK, gibi) de görülebileceği akılda tutularak transfüzyon kararı verilirken mutlaka kar-zarar oranı gözetilmelidir [11].

Bugüne kadar transfüzyonla ilgili rehberler bilimsel kanıt yetersizliği nedeniyle daha çok gözlemsel uzman deneyimlerine göre belirlenmeye çalışılmıştır [4, 16]. TND 2021 yılı prematüre bebekler (özellikle $<32$ gebelik haftası

Tablo 2. Yenidoğanlar için normal Hb değerleri [16]

\begin{tabular}{|c|c|c|c|}
\hline \multirow{3}{*}{ Yaş } & \multicolumn{3}{|c|}{ Hemoglobin konsantrasyonu (g/dL) } \\
\hline & \multicolumn{2}{|c|}{ Prematüre } & Term \\
\hline & $1000-1500 \mathrm{~g}$ & $1500-2000 \mathrm{~g}$ & \\
\hline 2. hafta & $16,3(11,7)$ & $14,8(11,8)$ & $16,5(12,5)$ \\
\hline 1. ay & $10,9(8,7)$ & $11,5(8,2)$ & $14,0(10,0)$ \\
\hline 2. ay & $8,8(7,1)$ & $9,4(8,0)$ & $11,5(9,0)$ \\
\hline 3. ay & $9,8(8,9)$ & $10,2(9,3)$ & $11,5(9,5)$ \\
\hline
\end{tabular}

Tablo 3. Türk Neonatoloji Derneği eritrosit transfüzyonu eşik Hb değerleri [16]

\begin{tabular}{lll}
\hline Postanatl yaş & *Solunum desteği olan $\mathbf{H b}(\mathbf{g} / \mathbf{d l})$ & Solunum desteği yok veya minimal $\mathbf{~ b}(\mathbf{g} / \mathbf{d l})$ \\
\hline$<1$ hafta & 11,5 & 10 \\
1-2 hafta & 10,5 & 9 \\
2-3 hafta & 9,5 & 8 \\
$\geq 4$ hafta & 8,5 & 7 \\
\hline
\end{tabular}

$\mathrm{Hb}$; hemoglobin, *Solunum desteği kriterleri; hedef satürasyonu \%90-95 aralığnda tutmak için yüksek frekanslı ventilasyon, konvansiyonel mekanik ventilasyon, non-invazif ventilasyon, $>2$ L/dk'dan yüksek frekanslı nazal kanül (HFNC) veya $\mathrm{FiO}_{2}$ gerkesiniminin > \%35 olması olarak tanımlanırken, minimal solunum desteği veya solunum desteği olmayan bebeklerde kriterler; hedef satürasyonu \%90-95 aralığında tutmak için <2 L/dk'dan HFNC, oksijen gereksiniminin olmaması veya FiO 2 gereksiniminin \%21-35 aralığında olması olarak tanımlanmaktadır [16] 
ve/veya $<1500$ gram) eritrosit süspansiyonu transfüzyonu için eşik $\mathrm{Hb}$ değerleri Tablo 3'de verilmiştir [16].

Tablo 3'de TND önerisine göre eşik $\mathrm{Hb}$ değerinin altındaki bebeklere hemen transfüzyon yapılmamalı, transfüzyon planlanmalı, ancak bu bebekler klinik açıdan yatak başında semptom açısından değerlendirilerek transfüzyon kararı verilmelidir. Bu semptomlar; a) 24 saati geçen taşikardi (kalp tepe atımı >180/dk) veya takipne (solunum sayısı $>60 / d k$ ) olması b) son 48 saatte oksijen gereksiniminin iki katına çıkması c) kan laktat düzeyinin $\geq 2,5 \mathrm{mEq} / \mathrm{L}$ veya akut metabolik asidoz $(\mathrm{pH}<7,2)$ olması d) son 4 günde $>120 \mathrm{kcal} / \mathrm{kg} /$ gün enerji alırken kilo alımının $<10 \mathrm{~g} / \mathrm{kg} / \mathrm{gün}$ olması e) 72 saat içinde majör cerrahi işlem yapılacak olması olarak sıralanmakta ve bunlardan herhangi birinini varlığında transfüzyon yapılması önerilmektedir. Ancak, prematüre bir bebekte $>\% 20$ kan kaybı varsa, \%10-20 kan kaybı ve eşlik eden asidoz gibi oksijen dağılımında yetersizlik veya hemodinamide bozulma durumu eşilik ediyorsa veya kanamanın devam ettiği akut kan kaybı ile giden durumlar varlığında acil transfüzyon uygulanması önerilmektedir [16]. Ayrıca, klinik semptomları anemi ile ilişkili olduğu düşünülen ve doku oksijenlenmesinin acil düzeltilmesi gereken yenidoğan bebeklerde transfüzyon kararının eşik $\mathrm{Hb}$ değerlerinden bağımsız alınması gerektiği de belirtilmektedir. Özellikle hemokonsantrasyon veya hemodilüsyon durumlarının varlığında eşik $\mathrm{Hb}$ değerleri çok dikkatliyorumlanmalı ve santral $\mathrm{Hb} / \mathrm{Htcölçümüile}$ değerlendirilmelidir [16]. 2019 yılında yayınlanan Avrupa Respiratuvar Distres Sendromu (RDS) klavuzunda ciddi kardiyopulmoner hastalığı olan bebeklerde eşik Hb değeri 12 g/dl, oksijen bağımlı ise $11 \mathrm{~g} / \mathrm{dl}$ ve postnatal 2 haftadan sonra stabil bebeklerde eşik $\mathrm{Hb}$ değeri $7 \mathrm{~g} / \mathrm{dl}$ olması gerektiği bildirilmektedir [17]. Buna ek olarak 2020 yılında yayınlanan önerilere göre; ciddi kardiyopulmoner hastalığı olan (mekanik ventilasyon ve $\mathrm{FiO}_{2}>0,35$ ) yenidoğanlarda eşik Htc değerlerinini \%40-45, orta düzeyde kardiyopulmoner hastalığı olanlarda \%30-40, ciddi cerrahi girişim gerektirende \%30-35 ve stabil bebeklerde ise $\% 20-25$ 'in üzerinde olması gerektiği belirtilmektedir [18].

Prematüre bebekler başta olmak üzere tüm yenidoğanların transfüzyonunda, lökositi azaltılmış ve/veya lökosit filtresi ile ışınlanmış (donörden kan alındıktan sonra 14 gün içinde 25 Gy gamma ışınlama yapılmalı ve sonrasında 24 saat içinde kullanılmalı) $A B O$ ve Rh uyumlu, son Htc düzeyi \%60-70 olan eritrosit süspansiyonu kullanılmalıdır [16]. Transfüzyon hacmi genellikle $10-20 \mathrm{ml} / \mathrm{kg}$ ve veriliş hız $5-7 \mathrm{ml} / \mathrm{kg} /$ saat olarak önerilmektedir [16, 19]. Prematüre bebeklerde ertitrosit transfüzyonunda standart banka kanı (2-42 gün) ya da taze ( $\leq 7$ gün) kan kullanımı ile ilgili yapılan çalışma ve son meta analize bakıldığında; NEK, IVK, prematüre retinopatisi (ROP), bronkopulmoner displazi (BPD), mortalite ve enfeksiyon gibi yan etkiler bakımından bir farklılığın olmadığı ve yenidoğanlarda standart banka kanının güvenle kullanılabileceği bildirilmekle birlikte [20, 21], intrauterin transfüzyon ( $<5$ gün), büyük hacimli kan transfüzyonu (>25 ml/kg), kan değişimi, hipotansif şok, kardiyak cerrahi, ekstrakorporeal membran oksijenizasyonu yapılanlarda mümkün olduğunca taze kan kullanımı önerilmektedir [6, $16,19]$.

Metabolik tarama veya başka tetkikleri $(\mathrm{Hb}$ elektroforezi gibi) planlanan tüm yenidoğanlarda, transfüzyon sonrası etkilenme ve hatalı sonuçların önlenmesi adına transfüzyon öncesi kan örneğinin alınması gerektiği bildirilmektedir [16].

Kirpalani ve Whyte [22] ise 2019 yılında prematüre bebeklerde eritrosit transfüzyon kararı için kapiller $\mathrm{Hb}$ ve $\mathrm{Htc}$ değerlerini içeren bir tablo yayınlamışlardır (Tablo 4). Bu tabloyla kıyaslandığında; TND 2021 eritrosit transfüzyon rehberi güncellemesinin solunum desteği gereken grupta genel olarak benzer olduğu, ancak solunum desteği almayan grupta 2 . haftadan sonra ortalama $0,5 \mathrm{~g} / \mathrm{dL}$ daha düşük olduğu görülmektedir.

En son yayınlanan çok merkezli randomize kontrollü iki çalışma (the Effects of Transfusion Thresholds on Neurocognitive Outcomes of Extremely Low-Birth-Weight Infants "ETTNO" ve TOP) grubunun eritrosit transfüzyonu için önerdiği; daha düşük Htc değerlerinde uygulanan eritrosit transfüzyonu kısıtlı (restrictive) ve daha yüksek Htc değerlerindeki transfüzyon ise liberal transfüzyon olarak tanımlanmakta olup, eşik Htc değerleri Tablo 5 ve Tablo 6'da verilmiştir [23, 24].

\footnotetext{
Yenidoğanda optimal eritrosit transfüzyon eşik $\mathrm{Hb} / \mathrm{Htc}$ değerleri nedir?
} 
Tablo 4. Prematüre bebeklerde eritrosit transfüzyonu için kapiller Hb ve Htc değerleri [22]

\begin{tabular}{lll}
\hline Postanatal yaş & $\begin{array}{l}\text { Solunum desteği alan } \\
\text { Hb g/dL/(Htc \%) }\end{array}$ & $\begin{array}{l}\text { Solunumun desteği yok } \\
\text { Hb g/dL/(Htc \%) }\end{array}$ \\
\hline 1 hafta & $11,5 /(35)$ & $10,0 /(30)$ \\
2 hafta & $10,0 /(30)$ & $8,5 /(25)$ \\
3 hafta & $8,5 /(25)$ & $7,5 /(23)$ \\
\hline
\end{tabular}

$\mathrm{Hb}$; hemoglobin, Htc; hematokrit

Tablo 5. ETTNO çalışma grubuna göre eritrosit transfüzyonu için venöz/arteryel Htc değerleri [23]

\begin{tabular}{lllll}
\hline & \multicolumn{4}{c}{ Hematokrit (\%) eşik değeri } \\
Postnatal yaş & \multicolumn{2}{c}{ Kısıtlı transfüzyon } & \multicolumn{2}{c}{ Liberal transfüzyon } \\
& Kritik hasta* $^{*}$ & Non-kritik hasta & Kritik hasta* $^{*}$ & Non-kritik hasta \\
\hline$\geq 7$ gün & $<34$ & $<28$ & $<41$ & $<35$ \\
8-21 gün & $<30$ & $<24$ & $<37$ & $<31$ \\
$>21$ gün & $<27$ & $<21$ & $<34$ & $<28$ \\
\hline
\end{tabular}

*Kritik hasta tanımı için ektekilerden en az birinin olması gerekir: a) İnvazif mekanik ventilasyon

b) 24 saatlik süreçte $>12$ saat ve $\mathrm{FiO}_{2}>0,25$ CPAP intiyacı c) İnotrop/vazopressör tedavisi gerektiren dolaşım yetmezlikli NEK, akut sepsis veya patent duktus arterizus (PDA) tedavisi d) 24 saat içinde $>6$ apne atağı e) Pulse oksimetre ile oksijen satürasyonu $<\% 60$ olan $>4$ hipoksemik atak. Bunların dışında, zorunlu olmamak kaydıyla; majör cerrahi girişim, majör kanama (kan kaybı >\%10 total vücut volümü), açıklanamayan laktik asidoz (arteryel laktat $>4 \mathrm{mmol} / \mathrm{L}$ ) ve ön görülemeyen acil durumlar da kritik hasta grubuna alınabilir

Tablo 6. TOP çalışma grubuna göre eritrosit transfüzyonu için Htc değerleri [12, 24]

\begin{tabular}{lllll}
\hline & \multicolumn{4}{c}{ Hematokrit (\%) eşik değeri } \\
Postnatal yaş & Kritik hasta & Non-kritik hasta & Kritik hasta & Non-kritik hasta \\
\hline 1 hafta & 32 & 29 & 38 & 35 \\
2 hafta & 29 & 25 & 37 & 32 \\
$\geq 3$ hafta & 25 & 21 & 32 & 29 \\
\hline
\end{tabular}

Geçmişte kısıtlı ve liberal transfüzyonla ilgili yapılan en önemli randomize kontrollü iki çalışma IOWA ve PINT çalışmalarıdır [16, 25, 26]. IOWA (ÇDDA'lı 100 bebek) ve PINT (ADDA'lı 451 bebek) çalışmalarının her ikisinde de kıstlı eritrosit transfüzyon gruplarında eritrosit transfüzyon sıklığının (bir veya daha fazla) azaldığı, ancak sağ kalım, ROP ve BPD bakımından gruplar arasında anlamlı bir farklılığın olmadığı bildirilmiştir. Bununla birlikte IOWA çalışmasında kısıtı transfüzyon uygulanan grupta periventriküler lökomalazi (PVL) veya ciddi IVK ve apne sıklığında bir artış görüldüğü, dolayısıyla kısıtlı transfüzyon stratejisinin bu bebeklerde zararlı olabileceği bildirilirken, PINT çalışmasında serebral hasarlanmada bir fark olmadığı ancak, PINT çalışmasının devamı olan PINTOS çalışmasında bebekler düzeltilmiş 18-21 aylık dönemde nörolojik olarak değerlendirildiğinde liberal grupta hafif ve orta düzeyde bilişsel geriliğin daha az oranda görüldüğü ve post hoc analize göre liberal transfüzyonun daha iyi olabileceği bildirilmiştir [25-27]. En son bildirilen randomize kontrollü çok merkezli çalışmalar olan, ETTNO ve TOP sonuçlarına göre ise kısıtlı ve liberal transfüzyon gruplarıarasında ne mortalitene de nörogelişimsel sonuçlar bakımından uzun dönemde anlamlı bir farklılığın olmadığı rapor edilmiştir [6, 23, 24]. Ayrıca ETTNO çalışmasında sekonder sonuçlar olarak iki grup arasında ROP, NEK, BPD ve IVK bakımından da bir farklılığın olmadığı ve benzer olduğu görülmüştür [23]. ADDA'lı bebeklerde doğumdan postanatal 36 haftaya kadar geçen süre içerisinde kıstlı transfüzyon grubunun $\% 60$ 'ına, liberal transfüzyon uygulanan grubun ise \%79'una en az bir kez eritrosit transfüzyonu uygulanmıştır [23]. Günümüze kadar prematüre bebeklerde yapılan randomize kontrollü, kısıtlı ve liberal transfüzyon uygulamaları ve bu uygulamaların sonuçlarını içeren en önemli ve çok merkezli çalışmaların karşılaştırması Tablo 7'de özetlenmiştir. Tablo 7'de yer alan çalışmaların da içinde bulunduğu 6 randomize 


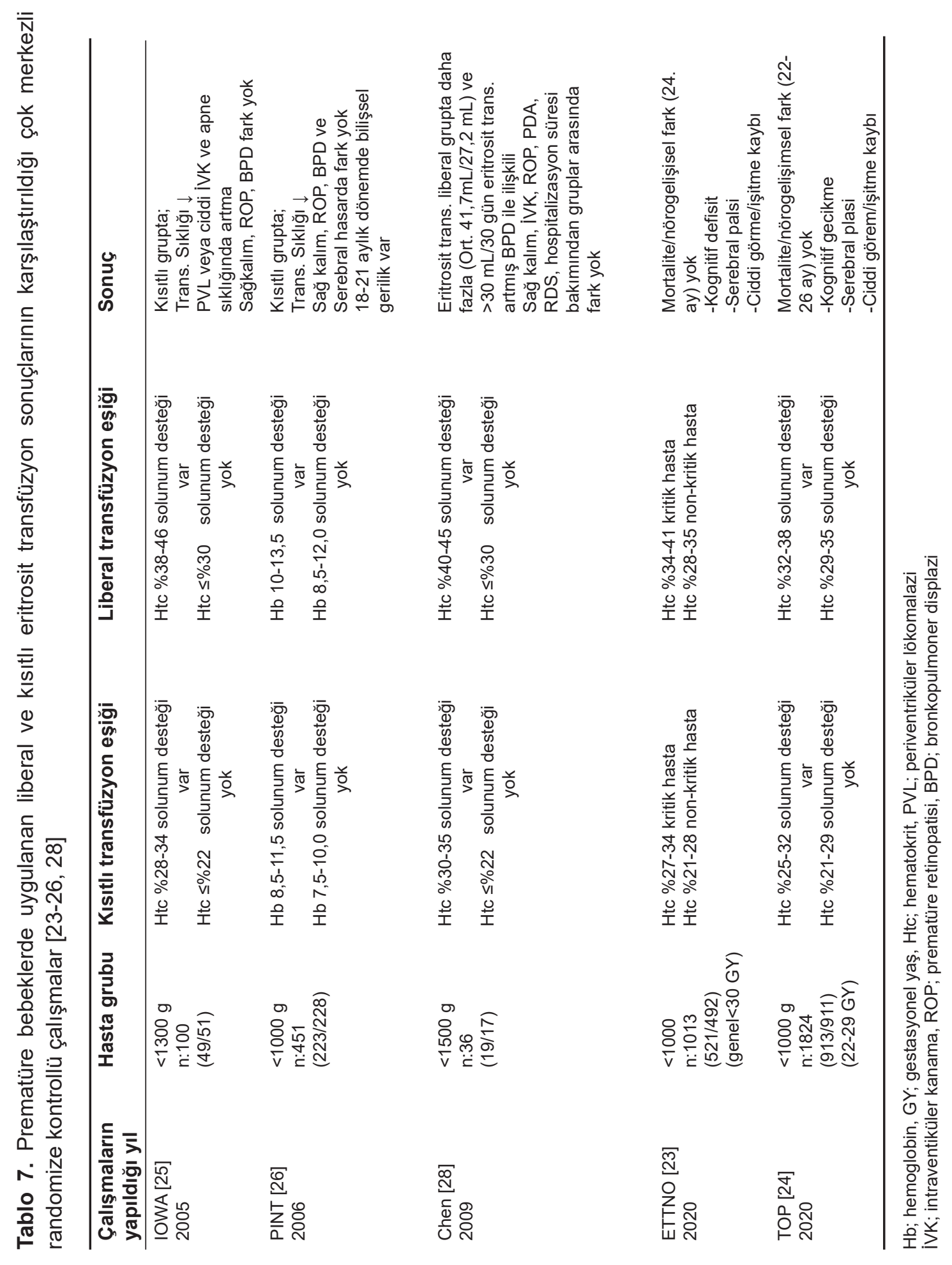


kontrollü çalışmanın dahil edildiği son meta analize bakıldığında; ÇDDA'lı bebeklerde kısa ya da uzun dönemde kısıtlı ertirosit transfüzyon Htc eşik değerinin artmış mortalite veya nöro gelişimsel bozukluk veya diğer ciddi yan etlkiler (BPD, NEK, ROP " $\geq$ evre III", intestinal perforasyon, sepsis, IVK " $\geq$ evre III", PVL ve hastanede kalış süresi) ile ilişkili olmadığı rapor edilmiştir [29]. Mevcut bulgular ışığında ve TND 2021 güncellemesinin de önerisiyle prematüre bebeklerde kısıtlı transfüzyon yaklaşımının uygulanması daha uygun gibi gözükmektedir [16].

\section{Korunma ve önlemler}

\section{Non-farmakolojik önlemler}

İyatrojenik kan kaybının mikroteknik içeren laboratuvar yöntemleriyle azaltılması ve noninvazif yöntemlerle hasta yönetiminin (oksijen ve karbondioksit izlemi gibi) sağlanması prematüre bebeklerde anemi gelişimi ve eritrosit transfüzyon intiyacını azaltmada oldukça önemlidir [4, 10, 30]. Aşırı düşük doğum ağırlıklı (<1000 g) 54 bebeğin alındığı bir çalışmada; postnatal ilk 10 haftalık takip süresinde, laboratuvar tetkikleri için kan alımına bağlı kan kayıplarının ilk haftalarda ve gebelik yaşı ile ters orantılı olarak arttığı ve bu süreçte ortalama kan kaybının transfüzyon öncesi yaklaşık $10 \mathrm{ml} / \mathrm{kg}^{\prime}$ । bulduğu belirtilmektedir [31]. Çok düşük doğum ağırlıklı (<1500 g) bebeklerde yapılan başka bir çalışmada tetkik için alınan kan örneği hacminin yarı yarıya azaltılmasıyla kan kaybının, transfüzyon ihtiyacı ve transfüzyon hacminin ve alınan tetkik sıklığının anlamlı oranda azaldığı gösterilmiştir [32]. Prematüre bebeklerde flebotomi sıklığının ve tetkik için alınan kan hacminin azaltılması bu bebeklerde kan transfüzyon ihtiyacının belirgin olarak azaltılmasında son derece önemli gözükmektedir. Prematüre bebeklerde başlangıç testleri için kord kanı kullanılması, flebotomi nedeniyle olan kan kaybını azaltabilir [6]. Prematüre bebeklerde kan kaybını önlemeye yönelik çalışmaların değerlendirildiği son meta analizde; mikro laboratuvar ölçüm yöntemleri ile ilgili olarak verilerin yetersiz ve kanıt düzeyi düşük olmakla birlikte mikro yöntemlerin bu bebeklerde kan kaybını azaltabileceği, ancak bununla ilgili kapsamlı çalışmalara intiyaç duyulduğu bildirilmektedir [30].

Doğum sonrası göbek kordonunun klemplenme zamanı veya kordun sağılmasıyla ilgili çalışmalarda; geç kord klemplemenin Htc ve serum ferritin düzeylerini arttırdığı, mortaliyeti ve IVK riskini azalttığı, kan transfüzyonunda \%10 azalma sağladığı, ancak kord sağmanın aşırı prematüre $(<28$ gebelik haftası) bebeklerde ciddi IVK riskini arttırdığı, hatta bazı çalışmalarda RDS riskini arttıryor gözüktüğü belirtilmekte olup, prematüre bebeklerde ideal kord uygulama yönteminin halen net olarak ne olduğununu bilinmediği, ancak erken kord klemplemenin (<30 sn) prematüre bebeklerde zararlı olabileceği nedeniyle bu bebeklere erken kord klemplemenin önerilmemesi gerektiği bildirilmektedir [6, 33-40]. Kord sağma işlemi prematüre bebeklerde serebrovasküler ve sistemik kan akımında fluktuasyonlara neden olabileceği için şu an önerilmemektedir [10]. Ayrıca, gecikmiş kord klemplemenin polisitemi ve fototerapi gerektiren sarılık gibi minör bazı yan etkilerinin de görülebileceği belirtilmektedir [10]. Doğum sonrası göbek kordunu uygulamaları (erken kord klempleme, geç kord klempleme ve kordon sağma) ile ilgili son çalışma ve meta analizlerin sonuçları Tablo 8'de özetlenmiştir.

TND Doğum Salonu Yönetim Rehberi 2021 Güncellemesi canlandırma gerektirmeyen tüm term ve prematüre bebeklerin kordon klemplenmeden önce en az 30-60 saniye süreyle anne düzeyinde veya altında tutulmasını önermektedir [41].

Otolog ya da allojenik kord kanı transfüzyonu ile ilgili olarak ise prematüre bebeklerde otolog kord kanı transfüzyonu için büyük volümlere intiyaç olması nedeniyle başarının az olduğu, ancak alternatif olan allojenik kord kanı transfüzyonunun ise gelecekte donör kanı intiyacını azaltacağı ve neonatal transfüzyon pratiğinde önemli role sahip olabileceği belirtilmektedir [10].

\section{Farmakolojik önlemler}

Eritropoeitinin prematüre bebeklerde eritropoezisi etkili bir şekilde stimüle ettiği gösterilse de eritrosit transfüzyon intiyacını azaltmada ve uzun dönem nörolojik sonuçlarıyla ilgili çelişkili sonuçlar bildirilmektedir [6].

Eritropoezisi stimüle eden ajan olarak rekombinant human EPO (rhEPO) kullanımıyla ilgili çalışmalara bakıldığında; erken dönemde (<8 gün) rhEPO kullanımının eritrosit transfüzyon 
Tablo 8. Prematüre bebeklerde geç kord klempleme ve kord yönetimiyle ilgili bildirilen son randomize kontrollü çalışmalar ve meta analiz sonuçları

Erken ( $<30 \mathrm{sn}$ ) ve geç kord klempleme ( $\geq 30 \mathrm{sn}$, çoğunlukla $\geq 60 \mathrm{sn}$ ) ile ilgili 18 randomize kontrollü çalışma (n:2834) sonucu: geç kord klempleme ile hastanede mortalite azalmakta, kan transfüzyonunda \%10 azalma, Htc \%2,7 artış olmakta ancak; IVK, kronik akciğer hastalığı, NEK ve ROP üzerine etkisi bulunmamaktadır [33].

Prematürelerde geç kord klempleme ile ilgili süre net değil ancak, prematürelerde erken kord klempleme $(<30 \mathrm{sn})$ önerilmemektedir ([34].

Geç kord klempleme prematürelerde postnatal 6-10 haftalık süreçte Htc ve serum ferritin düzeylerini hafifçe arttırmaktadır [35].

Umblikal kord sağmayla ilgili prematüre bebeklerde (<37 bebelik haftası, n:2083) yapılan meta-analizde; transfüzyon intiyacının azaldığı, Hb ve ortalama kan basıncının arttığı, RDS riskinin arttığı gözükmektedir [36].

34 gebelik haftası altında doğan (n:5772) 42 randomize kontrollü çalışmanın dahil edildiği meta analizde; prematürelerde geç kord klempleme hematolojik parametreleri muhtemelen düzeltmekte, ancak majör neonatal sonuçlar üzerine etkisinin olmayabileceği, kord sağmayla ilgili ek çalışmalara ihtiyaç olduğu, prematürelerde ideal kord uygulamasının ne olduğunun halen net bilinemediği, ancak erken kord klemplemenin bu bebeklerde zararlı olabileceği bildirilmiştir [37]

Geç preterm ve term bebeklerde de erken kord klemplemeye kıyasla geç kord klempleme ve kord sağma işlemi postnatal erken dönemde $\mathrm{Hb}$ ve $\mathrm{Htc}$ düzeylerini arttırmaktadır [38].

Acil kord klempleme ile geç kord klemplemenin kıyaslandığı başka bir meta analizde (56 çalışma, n:6852 prematüre); geç kord klempleme ile IVK, eritrosit transfüzyon intiyacı ve moratalite azalmıştır. Umblikal kord sağmayla da IVK ve eritrosit transfüzyon ihtiyacının azaldığı görülmüş, geç kord klempleme ile kord sağma arasında bir farklılık bulunmamış olmakla birlikte bu konuda ek çalışmalara intiyaç duyulduğu belirtilmiştir [39]. Ancak, aşırı prematüre bebeklerde (<28 gebelik haftası) kord sağmanın ciddi IVK riskini artırdığı saptanmıştır [40].

Htc; hematokrit, IVK; intraventriküler kanama, NEK; nekrotizan enterokolit

$\mathrm{ROP}$; prematüre retinopatisi, $\mathrm{Hb}$; hemoglobin, RDS; respiratuvar distres sendromu

intiyacını bir miktar (ortalama $7 \mathrm{ml} / \mathrm{kg}$ ) azalttığı, ancak istatistiksel olarak anlamlı olmasa da evre $\geq 3$ ROP riskini arttırdığı belirtilmektedir. Geç rhEPO uygulamasının ise bir yararı yoktur. Dolayısıyla uluslararası rehberler rutin rhEPO kullanımını minimal yararları ve olası yan etkileri nedeniyle önermemektedir [10]. Erken ve geç EPO (<8 gün ve $\geq 8$ gün) uygulamasının kıyaslandığında 262 bebeği içeren iki randomize kontrollü çalışmada; erken EPO'nun geç EPO'ya kıyasla eritrosit transfüzyon intiyacını azaltmada anlamlı bir fayda sağlamadığı gibi ROP riskini de anlamlı olarak arttırdığı gösterilmiştir [42]. Erken EPO (<8 gün) uygulanan 34 çalışma ve 3643 prematüre bebeğin alındığı ve plasebo ya da tedavisiz grupla kıyaslandığı başka bir meta analizde; yüksek ( $\geq 500 \mathrm{iu} / \mathrm{kg} / \mathrm{hafta}$ ) ya da düşük ( $\leq 500 \mathrm{iu} / \mathrm{kg} / \mathrm{hafta}$ ) dozda erken EPO'nun kanıt düzeyi düşük olmakla birlikte bir veya daha fazla eritrosit transfüzyon intiyacını azalttığı ("number need to treat" NNT: 7; transfüze edilen kan volümünün totalde hasta başına $7 \mathrm{ml} / \mathrm{kg}$ azalttığı) aynı zamanda NEK riskini (NNT: 33), IVK ve PVL riskini azalttığı; düzeltilmiş yaşı 1822 aylık bebeklerde nörogelişimsel sonuçların daha iyi olduğu (Bayley II Mental Development Index skorlarının daha iyi olduğu), mortalite üzerine etkisiz ve evre $\geq 3$ ROP riskinde anlamlı bir farklılığın olmadığı bildirilmekte, ancak kıstlı faydaları nedeniyle şu an için EPO kullanımı önerilmemektedir [43].

Demir süplementasyonuyla ilgili olarak, demirin önemli bir kısmı gebeliğin son trimestirinde fetüsa geçtiği, dolayısıyla tüm prematüre bebeklerin term bebeklere kıyasla ferritin depolarının eksik olarak doğduğu, ancak en fazla etkilenmenin aşırı prematürelerde görüldüğü bildirilmektedir. Prematüre bebekler enteral beslenmeyi tolere ettiğinde $(100 \mathrm{ml} /$ $\mathrm{kg})$ demir süplementasyonunun $(2-3 \mathrm{mg} / \mathrm{kg} /$ gün) erkenden (<28 gün) başlanılmasının, bu bebeklerde nörolojik fonksiyonlar üzerine olumlu etkilere sahip olduğu belirtilmektedir [10]. Ancak, 598 ÇDDA'lı bebekte yapılan bir çalışmada yüksek enteral demir süplementasyonunun (her $50 \mathrm{mg}$ kümülatif birikimde) BPD gelişimi ile ilişkili olduğu, yüksek volümde eritrosit transfüzyonuyla da $\mathrm{BPD}$ gelişimi arasında bir ilişki olduğu bildirilmektedir [44]. Demir süplementasyonun, bu bebeklere ne zaman ve hangi dozda verilmesi ve BPD ile ilişkisinin açıklanması adına geniş kapsamlı ek çalışmalara intiyaç olduğu bildirilmekle 
birlikte [6], demir süplementasyonu prematüre ve düşük doğum ağırlıklı bebeklerde demir depolarını düzeltmekte, demir eksikliği ve anemiyi azaltmaktadır [45, 46]. TND Prematüre ve Hasta Term Bebeğin Beslenmesi Rehberi 2018 Güncellemesi prematüre bebeklere 2-3 $\mathrm{mg} / \mathrm{kg} / \mathrm{gün}$ dozunda, en erken 2. haftada, ideali 6-8 haftada demir süplementasyonunun başlanması ve 12-15 aya kadar devam edilmesini önermektedir [47].

Sonuç olarak, optimal transfüzyon kriterleri için kanıtların yetersizliği ve transfüzyonun potansiyel yan etkileri nedeniyle yenidoğana eritrosit transfüzyonunda çok dikkatli olunması, asıl amacın yenidoğan anemisinin önlenmesi stratejisinin olmasının daha iyi olacağı belirtilmektedir. Bu maksatla geç kord klempleme (30-60 saniye) uygulamasının, laboratuvar testleri için iyatrojenik kan kaybının minimalize edilmesine yönelik kan ölçümlerinin azaltılması ya da buna yönelik mikro laboratuvar ölçüm yöntemlerinin kullanılması ve uygun nutrisyonel desteğin verilmesi stratejik olarak hem daha ucuz hem de daha uygulanabilir yöntemler olarak gözükmektedir [4].

\section{Transfüzyon komplikasyonları}

Bazı çalışmalarda eritrosit transfüzyonuyla ilişkili olarak transfüzyon uygulanan bebeklerde IVK, BPD ve ROP riskinde artış, hatta hastanede yatış sürecinde \%50'ye varan mortalitede de bir artış olduğu bildirilmektedir [12, 48]. Bazı çalışmalarda ise bunların transfüzyonla ilişkisiz olduğu; tüm bu risklerin düşük doğum ağırlığı, düşük gestasyonel yaş, uzun süreli oksijen tedavisine maruziyet ve anemik bebeklerde doku hipoksisi ile ilişki bir durum nedeniyle bu tür komplikasyonların gelişebileceği belirtilmektedir $[12,26]$. Bildirilen son randomize kontrollü çalışma ve meta analiz sonuçlarına göre ise kısıtlı ya da liberal transfüzyon stratejilerinin mortalite üzerine bir etksinini olmadığı, hatta ETTNO çalışmasında ROP, NEK, BPD ve IVK bakımından da gruplar arasında anlamlı bir farklılık olmadığı bildirilmektedir [23, 24, 49].

Eritrosit transfüzyonuyla IVK arasındaki ilişki net olmasa da ÇDDA'lı preterm bebeklerde yaşamın ilk haftasında endikasyon dışı eritrosit transfüzyonundan kaçınılması gerektiği belirtilmektedir [50-52].

TR-ROP çalışması ve ROP ile ilgili son meta analiz değerlendirmesinde özellikle doğum ağırlığı $\leq 1500$ gr veya gestasyonel yaşı $\leq 32$ hafta olan bebeklerde eritrosit transfüzyonunun ROP gelişimi için bağımsız bir risk faktörü olduğu daha büyükler için kanıtların yetersiz olduğu ve ek çalışmalara intiyaç duyulduğu rapor edilmektedir [53, 54]. Ayrıca, Türk Neonatoloji Derneği ve Türk Oftalmoloji Derneği ROP gelişiminde kan transfüzyonu ve kan değişimini başlıca risk faktörü olarak tanımlamaktadır [55].

Yine bazı çalışmalarda eritrosit transfüzyonu sonrası ilk 72 saat içinde NEK geliştiği (\%25-35 olguda) ile ilgili raporlar bulunmaktadır, ancak mekanizması tam olarak bilinmemektedir [12]. Anemik de olsa prematürelerde beslenme sonrası normalde süperior mezenterik arter kan akımında bir artış olduğu iyi bilinmektedir, ancak NEK gelişiminde barsak doku kan akımı ve perfüzyonunun bozulması oldukça önemli faktörler olarak kabul edilmektedir. Yapılan çalışmalarda transfüzyon sonrası erken dönemde mezenterik arter kan akımı artışı cevabının yetersiz olduğu ve bu durumun NEK gelişimine katkı sağlayabileceği belirtilmektedir [12]. Yakın tarihli ve 598 ÇDDA'lı bebeği içeren bir çalışmada ise ciddi aneminin $(\mathrm{Hb}<8 \mathrm{~g} / \mathrm{dl})$ kendisinin artmış NEK riski ile anlamlı ilişkili olduğu bildirilmektedir [12, 56]. Prematüre bebeklerde transfüzyonla ilişkili NEK gelişiminin değerlendirildiği son meta analizde, kanıt düzeyi düşük-orta olmakla birlikte transfüzyonla NEK gelişimi arasında anlamlı bir ilişkinin olmadığı, ancak bu konuda daha iyi kalitede ve kapsamlı çalışmalara intiyaç olduğu rapor edilmiştir [57]. Transfüzyon sırasında enteral beslenmeye ara verilmesinin transfüzyon ilişkili NEK gelişimini önlemesine yönelik çalışmaların değerlendirildiği son meta analizde bu konuyla ilgili kanıtların yetersiz olduğu bildirilmekle birlikte [58], 2021 yılı TND Nekrotizan Enterekolit Tanı, Tedavi ve Korunma Rehberi eritrosit transfüzyonu sırasında beslenmeye ara verilmesini [59], Hindistan Kan Ürünleri Kullanım Rehberi ise beslenmeye transfüzyondan 3 saat önce ara verilmesini ve transfüzyon bitene kadar beslenmemesini önermektedir [60].

Eritrosit transfüzyonunda, eritrosit süspansiyonunun depo süresinin transfüze edilen bebeklerdeki etkisinin incelendiği son meta analizde; kısa süreli (<7 gün) ya da uzun süreli olan eritrosit süspansiyonlarının yetişkin ve çocuklarda kısa dönemde (<30 gün) mortalite üzerine bir etkisinin olmadığı, yenidoğanlarla 
ilgili olarak ise yeterli verilerin bulunmadığı bildirilirken [20], ÇDDA'lı 377 bebeğin alındığı bir çalışmada taze (<7 gün) eritrosit süspansiyonu ile standart eritrosit süspansiyonu (2-42 gün) transfüze edilen bebeklerin 3 aylık izleminde; NEK, ROP, BPD, IVK, ölüm ve nozokomiyal enfeksiyon bakımından iki grup arasında anlamlı bir farklılığın olmadığı gösterilmiştir [21], ancak; yüksek volümlü transfüzyonlarda plazma potasyumunda artma, sitrat toksisitesine bağlı hipokalsemi gelişme riskleri bulunabilmektedir [6].

Prematüre bebeklerde yaşamı ilk dönemlerinde her bir eritrosit transfüzyonun uzun dönemde; kognitif gecikme, dil ve motor fonksiyonlarda azalma ile ilişkili olduğu, transfüzyon sayısının azaltılması ile bu nörolojik hasarlanma riskinin azalabileceği, dolayısıyla restriktif eritrosit transfüzyon eşik değeri kullanımının uzun dönemde potansiyel olarak daha nöroprotektif gözüktüğü bildirilmektedir [61-65].

Çocuklarda kan ve ürünlerinin transfüzyonuyla ilişkili olarak enfeksiyon, febril reaksiyonlar, allerjik reaksiyonlar, hemolitik ve non-hemolitik reaksiyonlar, anaflaksi ve graftversushostreaksiyonugibipekçokkomplikasyon gelişebilmektedir. Bu komplikasyonların görülme sıklığı yıllar içerisinde belirgin bir azalma gösterse de tümüyle kaybolmadığı, ancak kısıtlı eritrosit transfüzyon stratejisiyle transfüzyon sayısında \%44'lük bir azalma görüldüğü bildirilmektedir [66]. Ayrıca, transfüzyon öncesi transfüze edilecek hasta için seçilen kan ve/ veya kan ürünlerinin o hasta adına uygunluğu mutlaka transfüzyon ekibince kontrol edilerek transfüzyona başlanılması komplikasyonları en aza indirmek adına oldukça önemlidir.

Sonuç olarak, prematüre yenidoğanlarda eritrosit transfüzyonu sıklıkla hayat kurtarabileceği gibi yukarıda da belirtildiği üzere potansiyel bazı ciddi yan etkilere de neden olabilir. Bu nedenle, savunmasız ve oldukça hassas olan prematüre bebeklere eritrosit transfüzyon kararı verilirken, TND Kan Ürünleri Transfüzyon Rehberi 2021 Güncellemesi eşliğinde bebeğin klinik bulguları ve postnatal yaşına göre hasta başında bireyselleştirilmiş transfüzyon kararı verilmelidir. Son çalışmalar ışığında; kısıtlı ya da liberal transfüzyon eşik $\mathrm{Hb}$ değerlerinin kısa ya da uzun dönemde mortalite ya da ciddi morbidite üzerine etkileri arasında anlamlı bir farklılık bildirilmese de kısıtlı grupta daha az eritrosit transfüzyonuna maruz kalınmakta ve uzun dönem bulguları potansiyel olarak daha nöroprotektif gözükmektedir. Ayrıca kan transfüzyonunun potansiyel yan etkileri de düşünüldüğünde kısıtlı transfüzyon $\mathrm{Hb}$ eşik değerlerinin kullanımı daha uygun olmakla birlikte asıl amaç prematüre bebeklerde anemi gelişiminin önlenmesi olmalıdır.

Çıkar ilişkisi: Yazar çıkar ilişkisi olmadığını beyan eder.

\section{Kaynaklar}

1. Letterio J, Poteva I, Petrosiute A, Ahuja S. Hematologic and oncologic problems in the fetüs and neonate. In: Martin R, Fanaroff AA, Walsh MC, eds. Fanaroff \& Martin's neonatal-perinatal medicine, diseases of the fetus and infant. 11th ed. Philadelphia: Elsevier, 2020;1416-1475.

2. Gomella TL, Eyal FG, Bany Mohammed F. Gomella's Neonatology management, procedures, on-call problems, diseases, and drugs. 8th ed. New York: Mc Graw Hill, 2020;815-822.

3. Akpan U, Orth E, Moore R, et al. The hematopoietic system. In: Jnah AJ, Trembath AN, eds. Fetal and neonatal physiology for the advanced practice nurse. New York: Springer Publishing Company, 2019;381454.

4. Lopriore E. Updates in red blood cell and platelet transfusions in preterm neonates. Am J Perinatol 2019;36:37-40. https://dx.doi. org/10.1055/s-0039-1691775

5. Christensen RD. Neonatal ertythrocyte disorders. In: Gleason CA, Juul SE, eds. Avery's diseases of the newborn. 10th ed. Philadelphia: Elsevier, 2018;11521179 .

6. Zerra PE, Josephson CD. Transfusion in neonatal patients: review of evidence-based guidelines. Clin Lab Med 2021;41:15-34. https://dx.doi.org/10.1016/j. cll.2020.10.002

7. Steiner L. Erythrocyte. In: Chess PA, ed. Avery's neonatology board review. 1st ed. 2019;288-295.

8. Cibulskis CC, Maheshwari A, Rao R, Mathur AM. Anemia of prematurity: how low is too low? J Perinatol 2021;41:1244-1257. https://dx.doi.org/10.1038/s41372-021-00992-0

9. Christensen RD, Henry E. Reference intervals in neonatal hematology. Clin Perinatol 2015;42:483-497. https://dx.doi.org/10.1016/j.clp.2015.04.005

10. Saito Benz M, Flanagan P, Berry MJ. Management of anaemia in pre-term infants. $\mathrm{Br} J$ Haematol 2020;188:354-366. https://dx.doi.org/10.1111/bjh.16233 
11. Del VecchioA, Franco C, Petrillo F, D'Amato G. Neonatal transfusion practice: when do neonates need red blood cells or platelets? Am J Perinatol 2016;33:1079-1084. https://dx.doi.org/10.1055/s-0036-1586106

12. Howarth C, Banerjee J, Aladangady N. Red blood cell transfusion in preterm infants: current evidence and controversies. Neonatology 2018;114:7-16. https:// dx.doi.org/10.1159/000486584

13. Kalteren WS, Verhagen EA, Mintzer JP, Bos AF, Kooi EMW. Anemia and red blood cell transfusions, cerebral oxygenation, brain injury and development, and neurodvelomental outcpme in preterm infants: a systemic review. Front Pediatr 2021;9:644462. https:// dx.doi.org/10.3389/fped.2021.644462

14. Dror Y, Chan AKC, Baker JM, Avila ML. Hematology. In: MacDonald MG, Seshia MMK, eds. Avery's neonatology pathophysiology \& management of the newborn. 7th ed. Philadelphia: Wolters Kluwer, 2016;872-929

15. Lanzkowsky P. Anemia during the neonatal period. In: Lanzkowsky P, Lipton JM, Fish JD, eds. Lanzkowsky's manual of pediatric hematology and oncology. 6 th ed. Amsterdam: Elsevier, 2016;51-68.

16. Perk Y. Atasay B, Çetinkaya M. Türk Neonatoloji Derneği Kan Ürünleri Transfüzyon Rehberi 2021 Güncellemesi.

17. Sweet DG, Carnielli V, Greisen G, et al. European Consensus Guidelines on the Management of Respiratory Distress Syndrome-2019 Update. Neonatology 2019;115:432-450. https://dx.doi. org/10.1159/000499361

18. Jacquot C, Mo YD, Luban NLC. Blood component therapy for the neonate. In: Martin R, Fanaroff AA, Walsh MC, eds. Fanaroff \& Martin's neonatal-perinatal medicine, diseases of the fetus and infant. 11th ed. Philadelphia: Elsevier, 2020;1476-1503.

19. Villeneuve A, Arsenault V, Lacroix J, Tucci M. Neonatal red blood cell transfusion. Vox Sang 2021;116:366378. https://dx.doi.org/10.1111/vox.13036

20. Shah A, Brunskill SJ, Desborough MJ, Doree C, Trivella M, Stanworth SJ. Transfusion of red blood cells stored for shorter versus longer duration for all conditions. Cochrane Database Syst Rev 2018;12:CD010801. https://dx.doi.org/10.1002/14651858.CD010801.pub3

21. Fergusson DA, Hebert P, Hogan DL, LeBel L, Rovinez Bouali N, Smyth JA. Effect of fresh red blood cell transfusions on clinical outcomes in premature, very low-birth-weight infants: the ARIPI randomized trial. JAMA 2012;308:1443-1451. https://dx.doi. org/10.1001/2012.jama.11953

22. Kirpalani H, Whyte RK. What is new about transfusions for preterm infants? An uptodate. Neonatology 2019;115:406-410. https://dx.doi. org/10.1159/000499048
23. Franz AR, Engel C, Bassler D, et al. Effects of Liberal vs Restrictive Transfusion Thresholds on Survival and Neurocognitive Outcomes in Extremely Low-BirthWeight Infants The ETTNO Randomized Clinical Trial. JAMA 2020;324:560-570. https://dx.doi.org/10.1001/ jama.2020.10690

24. Kirpalani $\mathrm{H}$, Bell EF, Johnson $\mathrm{KJ}$, et al. A randomized trial of higher versus lower hemoglobin transfusion threshold for extremely low birth weight (ELBW) infants: The Transfusion of Prematures (TOP) Trial. 2020. Available at: https://plan.core-apps.com/pas2020/abst ract/6edec56c63f592adb37f205ea944d7d8. Accessed May 02, 2020

25. Bell EF, Strauss RG, Widness JA, et al. Randomized trial of liberal versus restrictive guidelines for red blood cell transfusion in preterm infants. Pediatrics 2005;115:1685-1691. https://dx.doi.org/10.1542/peds.2004-1884

26. Kirpalani H, Whyte RK, Andersen C, et al. The Prematur Infants in Need of Transfusion (PINT) study: a randomized, controlled trial of a restrictive (low) versus liberal (high) transfusion treshold for extremely low birth weight infants. J Pediatr 2006;149:301-307. https://dx.doi.org/10.1016/j.jpeds.2006.05.011

27. Whyte RK, Kirpalani H, Asztalos EV, et al., the PINTOS Study Group study. Neurodevelopmental outcome of extremely low birth weight infants randomly assigned to restrictive or liberal hemoglobin thresholds for blood transfusion. Pediatrics 2009;123:207-213. https:// dx.doi.org/10.1542/peds.2008-0338

28. Chen HL, Tseng HI, Lu CC, Yang SN, Fan HC, Yang $\mathrm{RC}$. Effect of blood transfusions on the outcome of very low body weight preterm infants under two different transfusion criteria. Pediatr Neonatol 2009;50:110-116. https://dx.doi.org/10.1016/S1875-9572(09)60045-0

29. Wang P, Wang X, Deng $H$, et al. Restrictive versus liberal transfusion threshold in very low birth weight infants: a systematic review with meta-analysis. PLoS One 2021:16;e0256810. https://dx.doi.org/10.1371/ journal.pone. 0256810

30. Persad E, Sibrecht G, Ringsten M, et al. Interventions to minimize blood loss in very preterm infants a systematic review and meta-analysis. PLoS One 2021;16:e0246353. https://dx.doi.org/10.1371/journal. pone. 0246353

31. Puia Dumitrescu M, TanakaDT, Spears TG, etal.Patterns of phlebotomy blood loss and transfusions in extremely low birth weight infants. J Perinatol 2019;39:1670-1675. https://dx.doi.org/10.1038/s41372-019-0515-6

32. Brener PH, Galletti MF, Carrascal MP, et al. Impact of the volume of blood collected by phlebotomy on transfusion requirements in preterm infants with birth weight of less than $1500 \mathrm{~g}$. A quasi-experimental study. Arch Argent Pediatr 2020;118:109-116. https://dx.doi. org/10.5546/aap.2020.eng.109 
33. Fogarty M, Osborn DA, Askie L, et al. Delayed vs early umbilical cord clamping for preterm infants: a systematic review and meta-analysis. Am J Obstet Gynecol 2018;218:1-18. https://dx.doi.org/10.1016/j. ajog.2017.10.231

34. Rabe H, Gyte GMI, Diaz Rossello JL, Duley L. Effect of timing of umbilical cord clamping and other strategies to influence placental transfusion at preterm birth on maternal and infant outcomes. Cochrane Database Syst Rev 2019;9:CD003248. https://dx.doi. org/10.1002/14651858.CD003248.pub4

35. Zhao Y, Hou R, Zhu X, Ren L, Lu H. Effects of delayed cord clamping on infants after neonatal period: a systematic review and meta-analysis. Int J Nurs Stud 2019;92:97-108. https://dx.doi.org/10.1016/j. ijnurstu.2019.01.012

36. Ortiz Esquina I, Gomez Salgado J, Rodriguez Almagro $\mathrm{J}$, Arias Arias A, Ballesta Castillejos A, Hernandez Martinez A. Umbilical cord milking in infants born at $<37$ weeks of gestation: a systematic review and meta-analysis. J Clin Med 2020;9:1071. https://dx.doi. org/10.3390/jcm9041071

37. Seidler AL, Gyte GML, Rabe H, et al. Umbilical cord management for newborns <34 weeks' gestation: a meta-analysis. Pediatrics 2021;147:e20200576. https://dx.doi.org/10.1542/peds.2020-0576

38. Gomersall J, Berber S, Middleton P, et al. Umbilical cord management at term and late preterm birth: a meta-analysis. Pediatric 2021;147:e2020015404. https://dx.doi.org/10.1542/peds.2020-015404

39. Jasani B, Torgalkar R, Ye XY, Syed S, Shah PS. Association of umbilical cord management strategies with outcomes of preterm infants: a systematic review and network meta-analysis. JAMA Pediatr 2021;175:e210102. https://dx.doi.org/10.1001/ jamapediatrics.2021.0102

40. Katheria A, Reister F, Essers J, et al. Association of Umbilical Cord Milking vs Delayed Umbilical Cord Clamping With Death or Severe Intraventricular Hemorrhage Among Preterm Infants. JAMA 2019;322:1877-1886. https://dx.doi.org/10.1001/ jama.2019.16004

41. Oygür N, Önal E, Zenciroğlu A. Türk Neonatoloji Derneği Doğum Salonu Yönetim Rehberi 2021 Güncellemesi.

42. Aher SM, Ohlsson A. Early versus late erythropoietin for preventing red blood cell transfusion in preterm and/or low birth weight infants (Review). Cochrane Database Syst Rev 2020;2:CD004865. https://dx.doi. org/10.1002/14651858

43. Ohlsson A, Aher SM. Early erythropoiesis-stimulating agents in preterm or low birth weight infants (Review). Cochrane Database Syst Rev 2020;2:CD004863. https://dx.doi.org/10.1002/14651858
44. Patel RM, Knezevic A, Yang J, Shenvi N, Hinkes M, Roback JD. Enteral iron supplementation, red blood cell transfusion, and risk of bronchopulmonary dysplasia in very-low-birthweight infants. Transfusion 2019;59:1675-1682. https://dx.doi.org/10.1111/trf.15216

45. Mills RJ, Davies MW. Enteral iron suplementation in preterm and low birth weight infants (review). Cochrane Database Syst Rev 2012:CD005095. https://dx.doi. org/10.1002/14651858

46. McCarthy EK, Dempsey EM, Kiely ME. Iron suplementation in preterm and low-birth-weightinfants: a systematic review of intervention studies. Nutr Rev 2019;77:865-877. https://dx.doi.org/10.1093/ nutrit/nuz051

47. Kültürsay $N$, Bilgen $H$, Türkyılmaz C. Türk Neonatoloji Derneği Prematüre ve Hasta Term Bebeğin Beslenmesi Rehberi 2018 Güncellemesi.

48. Crawford TM, Andersen CC, Hodly NA, Robertson SA, Stark MJ. The contribution of red blood cell transfuison to neonatal morbidity and mortality. J Paediatr Child Health 2019;55:387-392. https://dx.doi.org/10.1111/ jpc. 14402

49. Keir A, Sanchita P, Trivella M, et al. Adverse effects of red blood cell transfusions in neonates: a systematic review and meta-analysis. Transfusion 2016;56:27732780. https://dx.doi.org/10.1111/trf.13785

50. Lee EY, Kim SS, Park GY, Lee SH. Effect of red blood cell transfusion on short-term outcomes in very low birth weight infants. Clin Exp Pediatr 2020;63:56-62. https://dx.doi.org/10.3345/kjp.2019.00990

51. D'Amato G, Faienza MF, Palladino V, et al. Red blood cell transfusions and potentially related morbidities in neonates under 32 weeks' gestation. Blood Transfus 2021;19:113-119. https://dx.doi. org/10.2450/2020.0092-20

52. Çizmeci MN, Akın MA, Özek E. Türk Neonatoloji Derneği Germinal Matriks Kanaması-Intraventriküler Kanama ve Komplikasyonlarının Tanı ve Yönetim Rehberi 2021.

53. Bas AY, Demirel N, Koc E, Isik DU, Hirfanoğlu İM, Tunc T, TR-ROP Study Group. Incidence, risk factors and severity of retinopathy of prematurity in Turkey (TR-ROP study): a prospective, multicentre study in 69 neonatal intensive care units. $\mathrm{Br} \mathrm{J}$ Ophthalmol 2018;102:1711-1716. https://dx.doi.org/10.1136/ bjophthalmol-2017-311789

54. Zhu Z, Hua X, Yu Y, Zhu P, Hong K, Ke Y. Effect of red blood cell transfusion on the development of retinopathy of prematurity: a systematic review and meta-analysis. PLoS One 2020;15:e0234266. https:// dx.doi.org/10.1371/journal.pone.0234266

55. Koç E, Baş AY, Özdek Ş, Ovalı F. Türk Neonatoloji Derneği-Türk Oftalmoloji Derneği Türkiye Prematüre Retinopatisi Rehberi 2021 Güncellemesi. 
56. Patel RM, Knezevic A, Shenvi N, et al. Association of red blood cell transfusion, anemia, and necrotising enterocolitis in very low birth weight infants. JAMA 2016;315:889-897. https://dx.doi.org/10.1001/jama.2016.1204

57. Garg P, Pinotti R, Lal CV, Salas AA. Transfusionassociated necrotizing enterocolitis in preterm infants: an updated meta-analysis of observational data. J Perinat Med 2018;46:677-685. https://dx.doi. org/10.1515/jpm-2017-0162

58. Yeo KT, Kong JY, Sasi A, Tan K, Lai NM, Schindler T. Stopping enteral feeds for prevention of transfusionassociated necrotising enterocolitis in preterm infants. Cochrane Database Syst Rev 2019:CD012888. https:// dx.doi.org/10.1002/14651858

59. Ergenekon E, Tayman C, Özkan H. Türk Neonataolji Derneği Nekrotizan Enterekolit Tanı, Tedavi ve Korunma Rehberi 2021.

60. Use of blood components in newborn. Avaialble at:https://www.nnfi.org/assests/pdf/cpgguidelines/Blood \%20\%20components--Key\%20 Recommendations.pdf. Accessed December 02, 2021

61. Benavidesa A, Conrad AL, Brumbaugh JE, Magnotta $V$, Bell EF, Nopoulos P. Long-term outcome of brain structure in female preterm infants: possible associations of liberal versus restrictive red blood cell transfusions. J Matern Fetal Neonatal Med 2021;34:3292-3299. https://dx.doi.org/10.1080/14767 058.2019 .1683157

62. Kalteren WS, Verhagen EA, Mintzer JP, Bos AF, Kooi EMW. Anemia and red blood cell transfusions, cerebral oxygenation, brain injury and development, and neurodevelopmental outcome in preterm infants: a systematic review. Front Pediatr 2021;9:644462. https://dx.doi.org/10.3389/fped.2021.644462

63. Fontana C, Raffaeli G, Pesenti N, et al. Red blood cell transfusions in preterm newborns and neurodevelopmental outcomes at 2 and 5 years of age. Blood Transfus 2020 Dec 1. https://dx.doi. org/10.2450/2020.0207-20

64. Lum TG, Sugar J, Yim R, et al. Two-year neurodevelopmental outcomes of preterm infants who received red blood cell transfusion. Blood Transfus 2021. https://dx.doi.org/10.2450/2021.0070-21

65. Vu PT, Ohls RK, Mayock DE, et al. and for the PENUT Consortium. Transfusions and neurodevelopmental outcomes in extremely low gestation neonates enrolled in the PENUT Trial: a randomized clinical trial. Pediatr Res 2021;90:109-116. https://dx.doi.org/10.1038/ s41390-020-01273-w
66. Goodnough LT, Panigrahi AK. Blood transfusion therapy. Med Clin N Am 2017;101:431-447. https:// dx.doi.org/10.1016/j.mcna.2016.09.012

Bu konuda geçen bazı bilgi ve Tablo'lar yazar tarafından 6-10Ekim 2021 tarihlerindeAntalya'da yapılan Ulusal Neonatoloji Kongresi'nde (UNEKO-29), 8 Ekim 2021 tarihinde "Neonatal Hematolojide Son Çalışmalar Işığında Yaklaşımlar" Panelinde "Prematürede Anemi ve Transfüzyon Politikaları" başlığı altında sunum olarak anlatılmıştır. 